\title{
Stability relationships of REE-bearing phosphates in an alkali-rich system (nepheline syenite from the Mariupol Massif, SE Ukraine)
}

\author{
MAGDALENA DUMAŃSKA-SŁOWIK ${ }^{1}$, BARTOSZ BUDZYŃ² ${ }^{2}$, WIESŁAW HEFLIK ${ }^{1}$ \\ AND MAGDALENA SIKORSKA ${ }^{3}$
}

${ }^{1}$ A GH University of Science and Technology, Faculty of Geology, Geophysics and Environmental Protection Department of Mineralogy, Petrography and Geochemistry, al. A. Mickiewicza 30, PL-30-059 Kraków, Poland. E-mail:dumanska@uci.agh.edu.pl

${ }^{2}$ Institute of Geological Sciences, Polish Academy of Sciences, Research Centre in Kraków, Senacka St. 1, PL-31002 Kraków, Poland.

${ }^{3}$ Polish Geological Institute-National Research Institute, 4 Rakowiecka St., PL-00-975 Warsaw, Poland.

\begin{abstract}
:
Dumańska-Słowik, M., Budzyń, B., Heflik, W. and Sikorska, M. 2012. Stability relationships of REE-bearing phosphates in an alkali-rich system (nepheline syenite from the Mariupol Massif, SE Ukraine). Acta Geologica Polonica, 62 (2), 247-265.

Primary REE-enriched fluorapatite and fluorbritholite-(Ce) in nepheline syenite from the Mariupol Massif (SE Ukraine), contain textural and chemical evidence of late- to post-magmatic metasomatic alteration. REE mobilization and replacement of the primary phases by fluid-mediated coupled dissolution-reprecipitation strongly depended on the distance between the altered minerals in the host rock. Fluorapatite and fluorbritholite-(Ce) forming individual pristine grains were partially replaced by the same phase with a new composition, resulting in the presence of patchy zoning in altered grains. The increased REE contents in altered fluorapatite rim domains are related to REE mobilization from the altered REE-depleted rim domains of the fluorbritholite-(Ce). The REEs were transported by a fluid with high $\mathrm{F}$ activity. The alteration of fluorapatite and fluorbritholite-(Ce) grains in contact resulted in the partial replacement of the primary phases by the same phase with a new composition, but also in the partial replacement of the fluorapatite by secondary monazite and fluorite. The REE mobilized from the fluorbritholite-(Ce) in the presence of a F-rich fluid in an alkali-rich system promoted formation of monazite as the new phosphate REE-host. The presence of secondary parisite in the altered domains of the fluorapatite and fluorbritholite-( $\mathrm{Ce})$ indicates a $\mathrm{CO}_{2}$ component in the fluid during metasomatic alteration.
\end{abstract}

Key words: Fluorapatite; Fluorbritholite; Monazite; Rare earth elements; Dissolutionreprecipitation; Mariupolite; Ukraine.

\section{INTRODUCTION}

The geochemical behaviour and stability relationships of rare earth elements (REE) -bearing phosphates have been a topic of broad interest for several decades. Apatite $\left[\mathrm{Ca}_{5}\left(\mathrm{PO}_{4}\right)_{3}(\mathrm{~F}, \mathrm{Cl}, \mathrm{OH})\right]$ and monazite [(REE,Th, $\left.\mathrm{U}) \mathrm{PO}_{4}\right]$ are two of the most common phosphate minerals, occurring in almost all varieties of igneous, metamorphic and sedimentary rocks, and two of the main hosts of REEs in the Earth's crust. The sig- 
nificant tolerance to structural distortion and chemical composition of apatite-group minerals contribute to the numerous geological, environmental/palaeoenvironmental and technological applications that require an understanding of the substitution mechanisms and other factors controlling the composition of apatites (cf. Pan and Fleet 2002). In general, the REE contents in apatite are low; however, extremely high concentrations of $\mathrm{REE}_{2} \mathrm{O}_{3}$ (up to ca. $18 \mathrm{wt} . \%$ ) in apatite were documented in nepheline syenite from the Ilímaussaq alkaline complex, South Greenland (Rønsbo 1989, 2008). Hence, REEs in alkaline rocks do not necessarily concentrate only in monazite as the major phosphate REE-host, giving us the potential to study REE partitioning.

Previous work on the stability relationships of apatite and monazite focused mainly on processes in silica-saturated crystalline rocks (e.g. Bingen et al. 1996; Broska and Siman 1998; Finger et al. 1998; Wing et al. 2003; Broska et al. 2005; Janots et al. 2006, 2008, 2011; Finger and Krenn 2007; Krenn and Finger 2007; Tomkins and Pattison 2007; Berger et al. 2008; Budzyń et al. 2010; Ondrejka et al. 2012). The textures most typically preserving the constituents of the reaction between REE phosphates and silicates are related to monazite breakdown and the subsequent formation of secondary fluorapatite-allanite-epidote coronas (e.g. Broska and Siman 1998; Finger et al. 1998). Since monazite and allanite stability relationhips are strictly dependent on fluid and bulk rock compositions (e.g. Lee and Dodge 1964; Lee and Bastron 1967; Spear 2010; Budzyń et al. 2011), the occurrence of allanite is unexpected in low-Ca and high-Na rocks such as syenites. Rather, fluorapatite, britholite and, potentially, monazite may be formed as the main hosts of REEs (cf. Rønsbo 1989, 2008; Budzyń et al. 2011). REE mobilization between these phases can be related to primary crystallization from the protolith or to late- to post-magmatic processes. The last two decades have brought significant interest in the metasomatic alteration of the REE-bearing phosphates, particularly in pseudomorphic partial replacements driven by fluidmediated coupled dissolution-reprecipitation, documented in nature (e.g. Harlov et al. 2003, 2007; Hetherington and Harlov 2008; Williams et al. 2011; Upadhyay and Pruseth 2012) and reproduced experimentally (e.g. Teufel and Heinrich 1997; SeydouxGuillaume et al. 2002; Harlov and Förster 2003; Harlov et al. 2005, 2011; Hetherington et al. 2010; Budzyń et al. 2011; Williams et al. 2011; Harlov and Wirth 2012).

This study documents the stability relationships of REE-enriched fluorapatite, fluorbritholite-(Ce) and monazite in mariupolite, a leucocratic variety of nepheline syenite from the Mariupol alkaline massif (NW part of the eastern Priazovian region, Ukraine). The primary magmatic accessory phases, i.e. fluorapatite and fluorbritholite-(Ce), show evidence of low temperature alteration resulting from fluid-aided coupled dissolution-reprecipitation. Recognition of these processes is crucial in understanding mineral-fluid interactions, stability relationships and REE-partitioning between phosphates.

\section{GEOLOGICAL BACKGROUND AND SAMPLE DESCRIPTION}

The Mariupol (Oktyabrski) alkaline massif (Ukrainian Shield, south-eastern Ukraine), which covers an area of ca. $34 \mathrm{~km}^{2}$ (e.g. Krivdik et al. 2007), is a unique province of Proterozoic alkaline magmatism, with an age constrained to ca. $1.8 \mathrm{Ga}$ (Volkova 2000, 2001). The massif is formed mostly of alkaline syenites and foyaites, with minor amounts of aegirine-albite nepheline syenites (the so-called mariupolite; Morozewicz 1902, 1929), subalkaline gabbros, and their derivatives (peridotites, pyroxenites). Aegirine foyaites and agpaitic phonolites occur mainly among host granitoides in the outer parts of the massif (Text-fig. 1). The vast majority of rocks belong to an agpaitic suite (i.e. containg complex silicates enriched in zirconium, titanium, the rare earth elements, and fluorine) whilst mariupolite is an intermediate variety between miaskitic and agpaitic types (Sharygin et al. 2009). Mariupolite covers only a small area (ca. 5-10\%) of the whole massif. Further details on the massif can be found in Tichonienkova et al. (1967), Donskoy (1982), Solodov (1985), Volkova (2000; 2001) and Krivdik et al. (2007).

The leucocratic, fine- to medium-grained variety of nepheline syenite (mariupolite) shows porphyritic and chaotic or, locally, fluidal textures. The main mineral assemblage includes albite $\left(\mathrm{Ab}_{94-92} \mathrm{An}_{6-8}\right)$, nepheline and aegirine with subordinate amounts of lepidomelane, K-feldspar, pyrochlore, sodalite, natrolite, zircon, fluorite, cancrinite, fluorapatite, fluorbritholite and monazite. The predominant mineral is albite, forming fine prismatic grains with rare twinning, or large grains of an older generation defining the porphyritic fabric of the rock. The nepheline forms large, dynamically deformed crystals with patchy extinction. The lepidomelane and cancrinite grains concentrate mainly close to the sodalite and natrolite aggregates. The Kfeldspar forms large tabular grains, which occasionally reveal a crosshatched microcline pattern. Zircon crys- 

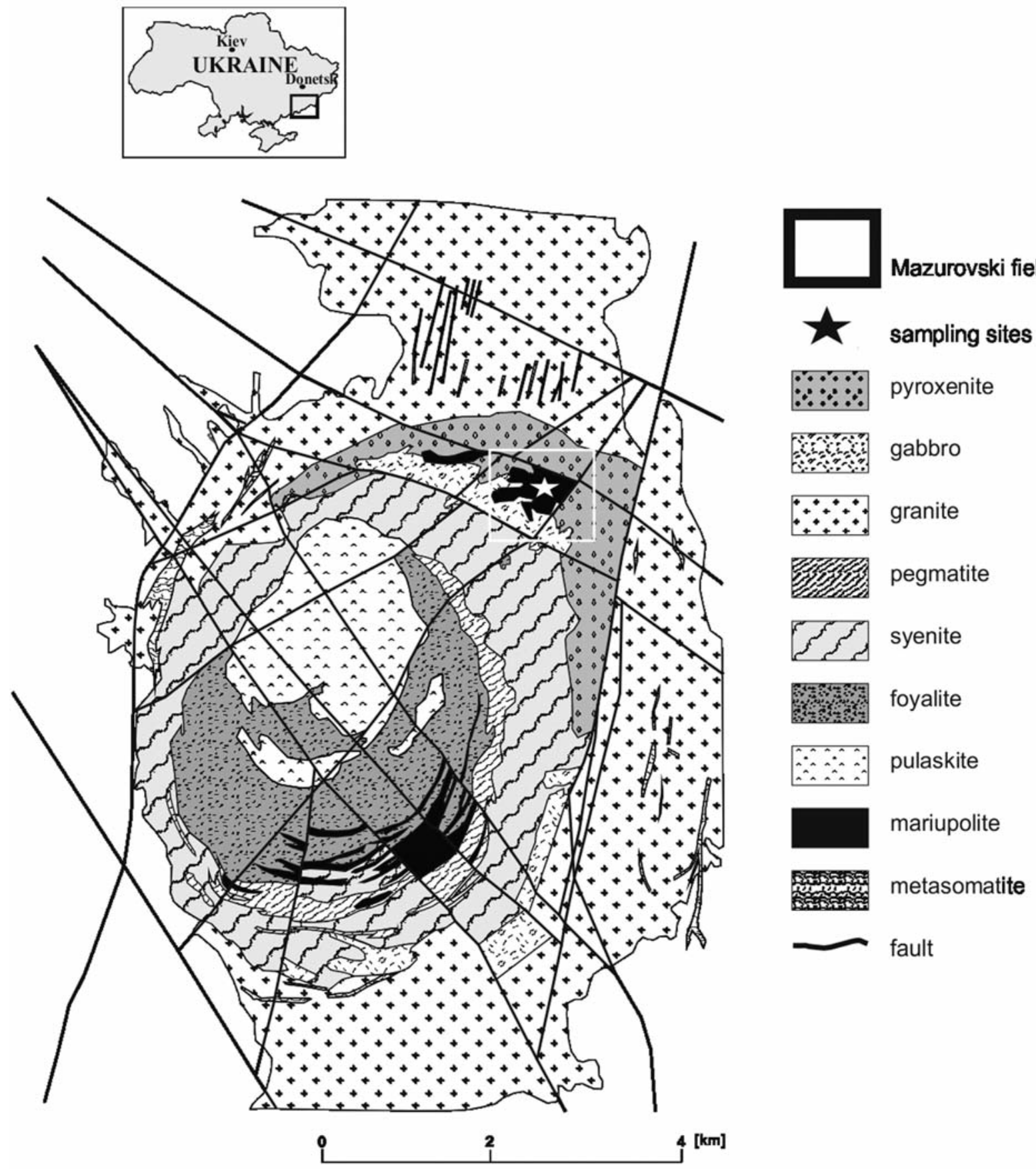

Text-fig. 1. A geological map of the Mariupol massif (SE Ukraine) (modified from Dumańska-Słowik et al. 2011b)

tallizes as euhedral grains with oscillatory zoning along the rims and irregular patchy zoning in the cores (Dumańska-Słowik et al. 2011a). Euhedral to subhedral grains of pyrochlore are present in the interstices between the albite grains. The pyrochlore is surrounded by coronas of acicular Fe-chlorite. A more detailed mineralogical description of the mariupolite is presented by Dumańska-Słowik et al. (2011b).

\section{ANALYTICAL PROCEDURES}

Preliminary observations were performed on polished thin sections using a FEI Quanta 200 field emission gun scanning electron microscope (SEM) equipped with an EDAX energy dispersive spectrometer (EDS) at the Department of Mineralogy, Petrography and Geochemistry, the AGH University of Science and Techno- 


\begin{tabular}{|c|c|c|c|c|c|c|c|c|c|c|c|c|c|c|}
\hline \multicolumn{5}{|c|}{ fluorapatite } & \multicolumn{5}{|c|}{ fluorbritholite } & \multicolumn{5}{|c|}{ monazite } \\
\hline \multicolumn{5}{|c|}{$\begin{array}{l}\text { acceleration voltage } 15 \mathrm{kV} \text {, } \\
\text { beam current } 10 \text { or } 20 \mathrm{nA}\end{array}$} & \multicolumn{5}{|c|}{$\begin{array}{l}\text { acceleration voltage } 15 \mathrm{kV} \text {, } \\
\text { beam current } 10 \text { or } 20 \mathrm{nA}\end{array}$} & \multicolumn{5}{|c|}{$\begin{array}{l}\text { acceleration voltage } 20 \mathrm{kV} \text {, } \\
\text { beam current } 50 \mathrm{nA}\end{array}$} \\
\hline element & signal & $\left|\begin{array}{c}\text { WDS } \\
\text { crystal }\end{array}\right|$ & standard & $\begin{array}{c}\text { estimated } \\
\text { detection } \\
\text { limit } \\
(\mathrm{ppm})\end{array}$ & element & signal & $\begin{array}{l}\text { WDS } \\
\text { crystal }\end{array}$ & standard & $\begin{array}{c}\text { estimated } \\
\text { detection } \\
\text { limit } \\
(\mathrm{ppm})\end{array}$ & element & signal & $\begin{array}{c}\text { WDS } \\
\text { crystal }\end{array} \mid$ & standard & $\begin{array}{l}\text { estimated } \\
\text { detection } \\
\text { limit } \\
(\mathrm{ppm})\end{array}$ \\
\hline $\mathrm{Pr}$ & $\mathrm{L} \beta$ & LIF & $\operatorname{PrP}_{5} \mathrm{O}_{14}$ & 2904 & $\mathrm{Ca}$ & $\mathrm{K} \alpha$ & PET & wollastonite & 285 & $P$ & $\mathrm{~K}_{a}$ & PET & apatite & 181 \\
\hline $\mathrm{Nd}$ & $\mathrm{L} \beta$ & LIF & $\mathrm{NdP}_{5} \mathrm{O}_{14}$ & 2993 & $\mathrm{La}$ & $\mathrm{L} \alpha$ & PET & $\mathrm{LaB}_{6}$ & 1124 & $\mathrm{La}$ & $\mathrm{L} \alpha$ & LIF & $\mathrm{LaB}_{6}$ & 652 \\
\hline $\mathrm{Mn}$ & $\mathrm{K}_{\alpha}$ & LIF & rhodonite & 879 & $\mathrm{Ce}$ & $\mathrm{L} \alpha$ & PET & $\mathrm{CeP}_{5} \mathrm{O}_{14}$ & 1129 & $\mathrm{Ce}$ & $\mathrm{L} \alpha$ & LIF & $\mathrm{CeP}_{5} \mathrm{O}_{14}$ & 466 \\
\hline $\mathrm{Sm}$ & $\mathrm{L} \beta$ & LIF & $\mathrm{SmP}_{5} \mathrm{O}_{14}$ & 2802 & $P$ & $\mathrm{~K}_{\alpha}$ & PET & apatite $\mathrm{BB}_{3}$ & 350 & $\operatorname{Pr}$ & $\mathrm{L}_{\beta}$ & LIF & $\operatorname{PrP}_{5} \mathrm{O}_{14}$ & 855 \\
\hline $\mathrm{Fe}$ & $\mathrm{K} \alpha$ & LIF & $\mathrm{Fe}_{2} \mathrm{O}_{3}$ & 777 & Th & $\mathrm{M} \alpha$ & PET & $\mathrm{ThO}_{2}$ synt & 2103 & $\mathrm{Nd}$ & $\mathrm{L} \beta$ & LIF & $\mathrm{NdP}_{5} \mathrm{O}_{14}$ & 788 \\
\hline $\mathrm{Gd}$ & $\mathrm{L} \beta$ & LIF & $\mathrm{GdP}_{5} \mathrm{O}_{14}$ & 2751 & U & $\mathrm{M} \beta$ & LIF & vorlanite & 1671 & $\mathrm{Sm}$ & $\mathrm{L} \beta$ & LIF & $\mathrm{SmP}_{5} \mathrm{O}_{14}$ & 1729 \\
\hline $\mathrm{Er}$ & $\mathrm{L} \alpha$ & LIF & REE1 & 3937 & $\mathrm{Cl}$ & $\mathrm{K}_{\alpha}$ & PET & tugtupite & 327 & $\mathrm{Gd}$ & $\mathrm{L}_{\beta}$ & LIF & $\mathrm{GdP}_{5} \mathrm{O}_{14}$ & 1508 \\
\hline Dy & $\mathrm{L} \beta$ & LIF & REE1 & 7211 & $\mathrm{~S}$ & $\mathrm{~K}_{\alpha}$ & PET & barite & 186 & $\mathrm{~Tb}$ & $\mathrm{~L}_{\beta}$ & LIF & $\mathrm{TbP}_{5} \mathrm{O}_{14}$ & 1550 \\
\hline $\mathrm{Yb}$ & $\mathrm{L} \alpha$ & LIF & REE3 & 3100 & $\operatorname{Pr}$ & $\mathrm{L}_{\beta}$ & LIF & $\mathrm{PrP}_{5} \mathrm{O}_{14}$ & 2904 & Dy & $\mathrm{L}_{\beta}$ & LIF & $\mathrm{DyP}_{5} \mathrm{O}_{14}$ & 1606 \\
\hline Ho & $\mathrm{L} \beta$ & LIF & REE2 & 7310 & $\mathrm{Fe}$ & $\mathrm{K}_{\alpha}$ & LIF & $\mathrm{Fe}_{2} \mathrm{O}_{3}$ & 777 & Ho & $\mathrm{L}_{\beta}$ & LIF & $\mathrm{HoP}_{5} \mathrm{O}_{14}$ & 1641 \\
\hline $\mathrm{F}$ & $\mathrm{K} \alpha$ & TAP & phlogopite & 2908 & $\mathrm{Mn}$ & $\mathrm{K} \alpha$ & LIF & rhodonite & 879 & $\mathrm{Er}$ & $\mathrm{L} \alpha$ & LIF & $\mathrm{ErP}_{5} \mathrm{O}_{14}$ & 839 \\
\hline $\mathrm{Na}$ & $\mathrm{K} \alpha$ & TAP & albite & 322 & $\mathrm{Nd}$ & $\mathrm{L}_{\beta}$ & LIF & $\mathrm{NdP}_{5} \mathrm{O}_{14}$ & 2993 & $\mathrm{Yb}$ & $\mathrm{L} \alpha$ & LIF & $\mathrm{YbP}_{5} \mathrm{O}_{14}$ & 914 \\
\hline $\mathrm{Sr}$ & $\mathrm{L} \alpha$ & TAP & $\mathrm{SrTiO}_{3}$ & 522 & $\mathrm{Sm}$ & $\mathrm{L} \beta$ & LIF & $\mathrm{SmP}_{5} \mathrm{O}_{14}$ & 2802 & $\mathrm{~Pb}$ & $\mathrm{M}_{\beta}$ & PET & $\mathrm{PbCrO}_{4}$ & 397 \\
\hline $\mathrm{Si}$ & $\mathrm{K}_{\alpha}$ & TAP & wollastonite & 216 & $\mathrm{Gd}$ & $\mathrm{L} \beta$ & LIF & $\mathrm{GdP}_{5} \mathrm{O}_{14}$ & 2751 & U & $\mathrm{M}_{\beta}$ & PET & vorlanite & 177 \\
\hline Y & $\mathrm{L} \alpha$ & TAP & YAG & 615 & $\mathrm{Er}$ & $\mathrm{L} \alpha$ & LIF & REE1 & 3937 & Th & $\mathrm{M} \alpha$ & PET & $\mathrm{ThO}_{2}$ synt & 525 \\
\hline $\mathrm{P}$ & $\mathrm{K} \alpha$ & PET & apatite $\mathrm{BB}_{3}$ & 350 & Dy & $\mathrm{L}_{\beta}$ & LIF & REE1 & 7211 & $\mathrm{Ca}$ & $\mathrm{K}_{\alpha}$ & PET & wollastonite & 64 \\
\hline $\mathrm{Ca}$ & $\mathrm{K} \alpha$ & PET & wollastonite & 285 & $\mathrm{Yb}$ & $\mathrm{L} \alpha$ & LIF & REE3 & 3100 & $\mathrm{~S}$ & $\mathrm{~K}_{\alpha}$ & PET & barite & 97 \\
\hline $\mathrm{Cl}$ & $\mathrm{K}_{\alpha}$ & PET & tugtupite & 328 & Ho & $\mathrm{L} \beta$ & LIF & REE2 & 7310 & Y & $\mathrm{L} \alpha$ & TAP & YAG & 221 \\
\hline $\mathrm{La}$ & $\mathrm{L} \alpha$ & PET & $\mathrm{LaB}_{6}$ & 977 & $\mathrm{~F}$ & $\mathrm{~K}_{\alpha}$ & TAP & phlogopite & 2344 & $\mathrm{Si}$ & $\mathrm{K}_{\alpha}$ & TAP & wollastonite & 76 \\
\hline $\mathrm{Ce}$ & $\mathrm{L} \alpha$ & PET & $\mathrm{CeP}_{5} \mathrm{O}_{14}$ & 970 & $\mathrm{Na}$ & $\mathrm{K}_{\alpha}$ & TAP & albite & 188 & & & & & \\
\hline As & $\mathrm{L} \alpha$ & TAP & GaAs & 500 & As & $\mathrm{L} \alpha$ & TAP & GaAs & 436 & & & & & \\
\hline $\mathrm{S}$ & $\mathrm{K} \alpha$ & PET & barite & 180 & $\mathrm{Si}$ & $\mathrm{K} \alpha$ & TAP & wollastonite & 216 & & & & & \\
\hline & & & & & $\mathrm{Sr}$ & $\mathrm{L} \alpha$ & TAP & $\mathrm{SrTiO}_{3}$ & 615 & & & & & \\
\hline & & & & & Y & $\mathrm{L} \alpha$ & TAP & YAG & 487 & & & & & \\
\hline
\end{tabular}

Table 1. Electron microprobe analyses conditions for REE minerals

logy, Kraków; and a LEO 1430 SEM equipped with an Oxford ISIS 300 system at the Polish Geological National Research Institute in Warsaw. Chemical analyses were conducted using a Cameca SX-100 electron microprobe at the Inter-Institute Analytical Complex for
Minerals and Synthetic Substances at Warsaw University. Electron microprobe operating conditions, standards and detection limits are presented in Table 1. The raw data were corrected using the PAP procedure (Pouchou and Pichoir 1985).

\begin{tabular}{|c|c|c|c|c|c|c|c|c|c|c|c|c|c|c|c|}
\hline Analyte Symbol & $\mathbf{S i O}_{2}$ & $\mathbf{A l}_{\mathbf{2}} \mathbf{O}_{\mathbf{3}}$ & $\mathbf{F e}_{2} \mathbf{O}_{\mathbf{3}}$ & $\mathbf{M n O}$ & $\mathbf{M g O}$ & $\mathbf{C a O}$ & $\mathbf{N a}_{2} \mathbf{O}$ & $\mathbf{K}_{\mathbf{2}} \mathbf{O}$ & $\mathbf{T i O}_{2}$ & $\mathbf{P}_{\mathbf{2}} \mathbf{O}_{\mathbf{5}}$ & $\mathbf{A s}$ & $\mathbf{S c}$ & $\mathbf{C r}$ & $\mathbf{L O I}$ & $\mathbf{T o t a l}$ \\
\hline Unit Symbol & $\%$ & $\%$ & $\%$ & $\%$ & $\%$ & $\%$ & $\%$ & $\%$ & $\%$ & $\%$ & $\mathrm{ppm}$ & $\mathrm{ppm}$ & $\mathrm{ppm}$ & $\%$ & $\%$ \\
\hline Detection Limit & 0.01 & 0.01 & 0.01 & 0.001 & 0.01 & 0.01 & 0.01 & 0.01 & 0.001 & 0.01 & 0.5 & 0.1 & 5 & 0.01 & 0.01 \\
\hline Mariupolite & 60.16 & 20.61 & 3.55 & 0.06 & 0.06 & 0.37 & 12.11 & 1.63 & 0.05 & $<0.01$ & 2.50 & 2.60 & $<5$ & 0.46 & 99.07 \\
\hline
\end{tabular}

\begin{tabular}{|}
\begin{tabular}{|c|c|c|c|c|c|c|c|c|c|c|c|c|c|c|c|c|c|}
\hline Analyte Symbol & Th & $\mathbf{U}$ & $\mathbf{Y}$ & $\mathbf{L a}$ & $\mathbf{C e}$ & $\mathbf{P r}$ & $\mathbf{N d}$ & $\mathbf{S m}$ & $\mathbf{E u}$ & $\mathbf{G d}$ & $\mathbf{T b}$ & $\mathbf{D y}$ & $\mathbf{H o}$ & $\mathbf{E r}$ & $\mathbf{T m}$ & $\mathbf{Y b}$ & $\mathbf{L u}$ \\
\hline Unit Symbol & $\mathrm{ppm}$ & $\mathrm{ppm}$ & $\mathrm{ppm}$ & $\mathrm{ppm}$ & $\mathrm{ppm}$ & $\mathrm{ppm}$ & $\mathrm{ppm}$ & $\mathrm{ppm}$ & $\mathrm{ppm}$ & $\mathrm{ppm}$ & $\mathrm{ppm}$ & $\mathrm{ppm}$ & $\mathrm{ppm}$ & $\mathrm{ppm}$ & $\mathrm{ppm}$ & $\mathrm{ppm}$ & $\mathrm{ppm}$ \\
\hline Detection Limit & 0.1 & 0.1 & 2 & 0.1 & 0.1 & 0.05 & 0.1 & 0.1 & 0.05 & 0.1 & 0.1 & 0.1 & 0.1 & 0.1 & 0.05 & 0.1 & 0.04 \\
\hline Mariupolite & 20.1 & 9.2 & 13 & 41.8 & 117 & 13.5 & 46.9 & 7.2 & 0.72 & 4 & 0.6 & 3.6 & 0.7 & 2.3 & 0.43 & 3.6 & 0.81 \\
\hline Analyte Symbol & $\mathbf{S c}$ & $\mathbf{B e}$ & $\mathbf{V}$ & $\mathbf{C r}$ & $\mathbf{C o}$ & $\mathbf{N i}$ & $\mathbf{C u}$ & $\mathbf{Z n}$ & $\mathbf{G a}$ & $\mathbf{G e}$ & $\mathbf{A s}$ & $\mathbf{R b}$ & $\mathbf{S r}$ & $\mathbf{Z r}$ & $\mathbf{N b}$ & $\mathbf{M o}$ \\
\hline Unit Symbol & $\mathrm{ppm}$ & $\mathrm{ppm}$ & $\mathrm{ppm}$ & $\mathrm{ppm}$ & $\mathrm{ppm}$ & $\mathrm{ppm}$ & $\mathrm{ppm}$ & $\mathrm{ppm}$ & $\mathrm{ppm}$ & $\mathrm{ppm}$ & $\mathrm{ppm}$ & $\mathrm{ppm}$ & $\mathrm{ppm}$ & $\mathrm{ppm}$ & $\mathrm{ppm}$ & $\mathrm{ppm}$ \\
\hline Detection Limit & 1 & 1 & 5 & 20 & 1 & 20 & 10 & 30 & 1 & 1 & 5 & 2 & 2 & 4 & 1 & 2 \\
\hline Mariupolite & 2 & 3 & 26 & $<20$ & 5 & $<20$ & $<10$ & 40 & 80 & 3 & $<5$ & 111 & 35 & 1812 & 620 & $<2$ \\
\hline
\end{tabular}
\end{tabular}

\begin{tabular}{|c|c|c|c|c|c|c|c|c|c|c|c|c|c|c|c|c|c|}
\hline Analyte Symbol & In & Sn & Sb & Cs & Ba & Hf & Ta & W & Tl & Pb & Bi & $\mathbf{C u}$ & Ni & $\mathbf{Z n}$ & $\mathbf{S}$ & $\mathbf{A g}$ & $\mathbf{P b}$ \\
\hline Unit Symbol & $\mathrm{ppm}$ & $\mathrm{ppm}$ & $\mathrm{ppm}$ & $\mathrm{ppm}$ & $\mathrm{ppm}$ & $\mathrm{ppm}$ & $\mathrm{ppm}$ & $\mathrm{ppm}$ & $\mathrm{ppm}$ & $\mathrm{ppm}$ & $\mathrm{ppm}$ & $\mathrm{ppm}$ & $\mathrm{ppm}$ & $\mathrm{ppm}$ & $\%$ & $\mathrm{ppm}$ & $\mathrm{ppm}$ \\
\hline Detection Limit & 0.2 & 1 & 0.5 & 0.5 & 3 & 0.2 & 0.1 & 1 & 0.1 & 5 & 0.4 & 1 & 1 & 1 & 0.001 & 0.3 & 5 \\
\hline Mariupolite & & 30 & $<0.5$ & $<0.5$ & 8 & 44.4 & 34.1 & 25 & 0.4 & 12 & $<0.4$ & 4 & 4 & 44 & 0.002 & 0.5 & $<5$ \\
\hline
\end{tabular}


Bulk-rock analyses were performed in the Actlabs Activation Laboratories Ltd., Ancaster, Ontario, Canada. The abundances of major oxides and trace elements were determined using Inductively Coupled Plasma-Optical Emission Spectrometry (ICP-OES) and Inductively Coupled Plasma-Mass Spectrometry (ICP$\mathrm{MS}$ ), following lithium metaborate/tetraborate fusion and dilute nitric digestion. Major oxides and trace elements were analysed using Thermo Jarrell-Ash ENVIRO II ICP or a Spectro Cirros ICP and Perkin Elmer SCIEX ELAN 6000 ICP-MS, respectively. Calibration was performed using multiple USGS and CANMET certified reference materials. The results of the whole rock analysis are presented in Table 2.

\section{RESULTS}

The phosphate mineral assemblage in the mariupolite comprises mainly fluorbritholite-(Ce) and fluorapatite, whilst monazite occurs in minor amounts. Both fluorbritholite-(Ce) and fluorapatite occur as individual matrix grains.

The fluorapatite forms anhedral, individual grains (up to $3 \mathrm{~mm}$ in size) dispersed in the mariupolite matrix near lepidomelane, feldspar, zircon and nepheline. It shows patchy zoning (c. 2) with dark domains in high contrast BSE imaging, which dominate in the inner parts of grains, while the bright domains are present along rims, and penetrate the grain interiors leaving the dark domains that seem to look like subgrains (Text-fig. 2). The bright domains along the rims show sharp boundaries with the internal zones, and occasionally contain inclusions of parisite (Text-fig. 2c). The fluorapatite is significantly enriched in REEs, and reflects some compositional variation between the domains. The bright domains contain 13.6-16.6 wt.\% $\mathrm{REE}_{2} \mathrm{O}_{3}$ versus $10.5-12.5$ wt. $\%$ in dark domains (Table 3). The Na content is also elevated, and differs between the bright and dark domains, i.e. from 2.2-2.6 wt. $\%$ to $1.6-1.8$ wt. $\% \mathrm{Na}_{2} \mathrm{O}$, respectively (Table 3 ). The enrichment in $\mathrm{Na}$ and REEs is accompanied by a decrease in the Ca content (Text-fig. 3). The concentrations of $\mathrm{Si}, \mathrm{Sr}$ and $\mathrm{Mn}$ are similar within the fluorapatite, and do not reflect variations between the internal domains.

The fluorbritholite-(Ce) usually occurs in association with albite, aegirine, zircon and pyrochlore. It forms individual anhedral matrix grains up to $700 \mu \mathrm{m}$ that exhibit patchy zoning in high contrast BSE imaging (Text-fig. 4). The boundaries between the bright and dark domains display irregular shapes. In general, the bright domains are present in the inner parts, while the rims are dominated by the dark domains. The grain boundaries show irregular, lobate shapes suggesting that the grains are corroded. Single inclusions of fluorapatite and natrolite concentrating mainly near the rims of the grain are found rarely. The fluorbritholite shows some variation in composition between bright and dark domains. The bright domains are enriched in REE (56.3-60.1 wt.\% $\mathrm{REE}_{2} \mathrm{O}_{3}$ ) compared to the dark domains (53.4-55.2 wt.\% $\mathrm{REE}_{2} \mathrm{O}_{3}$; Table 4). Simi-
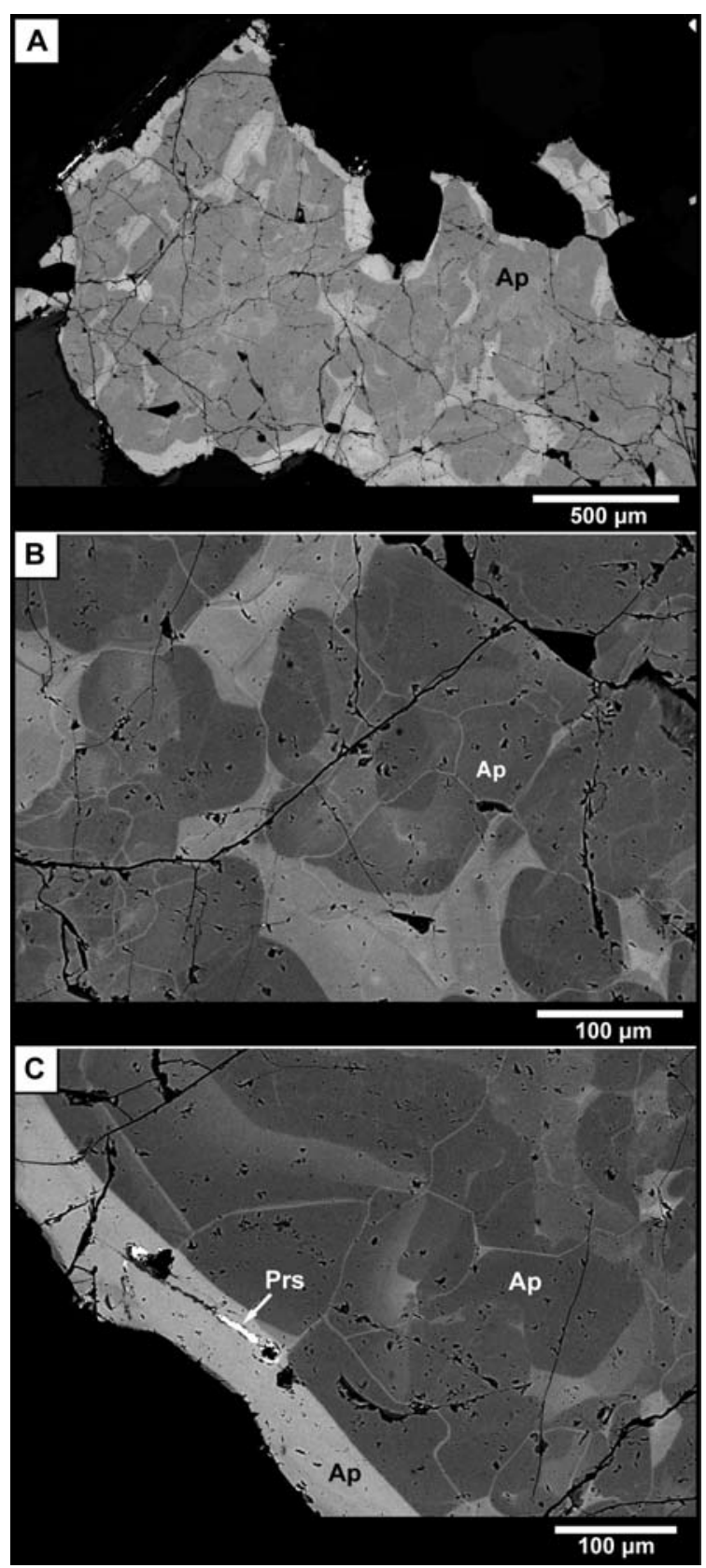

Text-fig. 2. The patchy zoned fluorapatite (Ap) grain in high contrast BSE imaging. Dark domains dominate in the core. Secondary parisite (Prs) inclusions occasionally are present in the bright compositional domains along rims 
larly, the bright domains are distinctly depleted in $\mathrm{Ca}$ and $\mathrm{Th}\left(13.3-15.1\right.$ wt.\% $\mathrm{CaO} ; 0.4-0.6$ wt. $\left.\% \mathrm{ThO}_{2}\right)$ in opposite to the dark patches domains (15.8-17.2 wt.\% $\mathrm{CaO} ; 0.7-1.5$ wt. $\% \mathrm{ThO}_{2}$ ). Hence, the distinct enrich- ment in REEs is accompanied by significant decrease of $\mathrm{Ca}+\mathrm{Th}$ content. Negative correlations of 2(REE) vs $\mathrm{Ca}+\mathrm{Th}(r=-0.979)$ and $\mathrm{Si}+\mathrm{REE}$ vs $\mathrm{Ca}+\mathrm{P}(r=-0.991)$ are observed in fluorbritholite-(Ce).
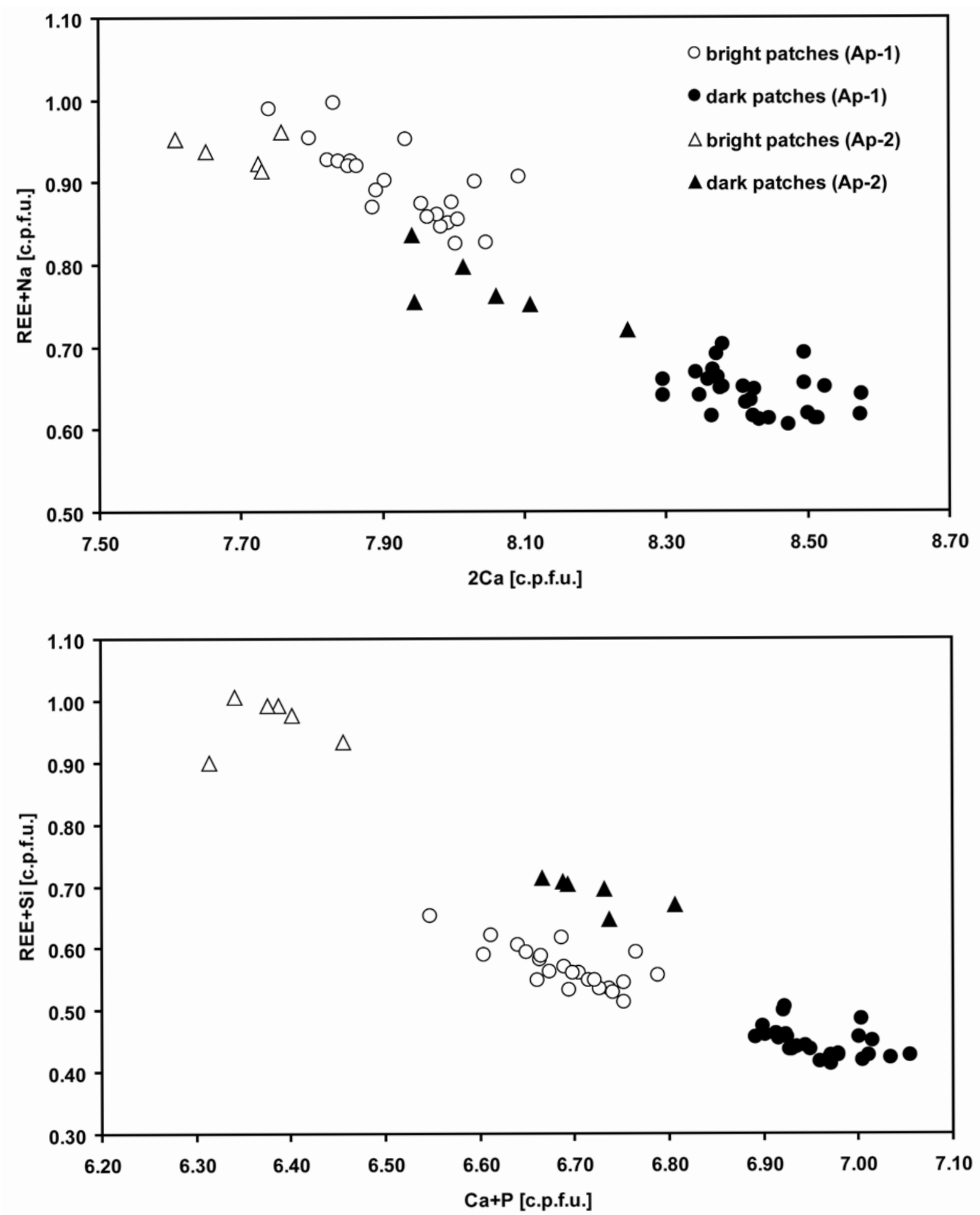

Text-fig. 3. Plots of formula proportions $2 \mathrm{Ca}$ vs. $(\mathrm{REE}+\mathrm{Na})$ and $(\mathrm{Ca}+\mathrm{P})$ vs. $(\mathrm{REE}+\mathrm{Si})$ calculated on the basis of $13 \mathrm{O}$ atoms for the fluorapatite in the mariupolite. Ap-1 - the fluorapatite present as individual grains; Ap-2 - the fluorapatite in contact with the fluorbritholite 
STABILITY RELATIONSHIPS OF REE-BEARING PHOSPHATES IN AN ALKALI-RICH SYSTEM

Fluorbritholite-(Ce) grains occasionally are closely associated with fluorapatite in the matrix. The grain boundaries between fluorbritholite-(Ce) and fluorapatite are filled with a fine-grained symplectite of monazite and fluorite grains, which are also present as inclusions within the fluorapatite (Text-fig. 5). The symplectitic monazite forms anhedral grains up to ca. $100 \mu \mathrm{m}$ in size. The monazite also forms elongated, up to ca. $200 \mu \mathrm{m}$, grains that partially surround the fluorapatite.
The fluorbritholite-(Ce) associated with fluorapatite shows patchy zoning in high contrast BSE imaging, with dark domains in the core and bright domains along the rims that occasionally contain small inclusions of arasite $\left[\mathrm{Ca}(\mathrm{Ce}, \mathrm{La})_{2}\left(\mathrm{CO}_{3}\right)_{3} \mathrm{~F}\right]$. The bright and dark domains contain similar concentrations of REEs (58.3-60.2 wt.\% vs. 58.6-58.9 wt. \% $\mathrm{REE}_{2} \mathrm{O}_{3}$, respectively), Th (0.9-1.1 wt.\% vs. $0.8-1.0$ wt. $\%$ $\mathrm{ThO}_{2}$, respectively) and $\mathrm{P}(2.2-3.4$ wt. $\%$ vs. $1.8-2.7$ wt. $\% \mathrm{P}_{2} \mathrm{O}_{5}$, respectively). The differences are found

\begin{tabular}{|c|c|c|c|c|c|c|c|c|c|c|c|c|}
\hline \multirow{2}{*}{$\begin{array}{l}\text { Region of crystal } \\
\text { Analysis }\end{array}$} & \multicolumn{12}{|c|}{$\begin{array}{l}\text { Individual pristine grain of fluorapatite } \\
\text { Bright domains }\end{array}$} \\
\hline & 1 & 10 & 15 & 18 & 24 & 25 & 26 & 31 & 34 & 35 & 105 & 110 \\
\hline $\mathrm{P}_{2} \mathrm{O}_{5}$ & 36.29 & 36.02 & 35.87 & 34.29 & 35.80 & 36.32 & 36.91 & 36.50 & 36.16 & 36.37 & 36.23 & 35.50 \\
\hline $\mathrm{SiO}_{2}$ & 0.79 & 0.93 & 1.00 & 1.09 & 0.93 & 0.91 & 0.79 & 0.74 & 0.77 & 0.85 & 0.76 & 1.11 \\
\hline $\mathrm{Y}_{2} \mathrm{O}_{3}$ & 0.46 & 0.50 & 0.39 & 0.43 & 0.43 & 0.41 & 0.35 & 0.44 & 0.42 & 0.35 & 0.41 & 0.42 \\
\hline $\mathrm{La}_{2} \mathrm{O}_{3}$ & 2.77 & 2.74 & 2.76 & 2.98 & 2.68 & 2.69 & 2.53 & 2.51 & 2.69 & 2.53 & 2.93 & 3.08 \\
\hline $\mathrm{Ce}_{2} \mathrm{O}_{3}$ & 6.58 & 6.97 & 6.99 & 7.41 & 6.59 & 6.75 & 6.47 & 6.13 & 6.60 & 6.61 & 7.10 & 7.31 \\
\hline $\mathrm{Pr}_{2} \mathrm{O}_{3}$ & 0.93 & 0.79 & 0.90 & 1.03 & 0.93 & 1.03 & 0.81 & 0.96 & 0.46 & 0.79 & 0.56 & 0.78 \\
\hline $\mathrm{Nd}_{2} \mathrm{O}_{3}$ & 3.67 & 3.62 & 3.24 & 3.85 & 3.43 & 3.49 & 3.28 & 3.14 & 3.44 & 3.23 & 3.74 & 3.88 \\
\hline $\mathrm{Sm}_{2} \mathrm{O}_{3}$ & 0.68 & 0.36 & 0.41 & 0.40 & & 0.51 & 0.74 & & 0.60 & 0.53 & & \\
\hline $\mathrm{Gd}_{2} \mathrm{O}_{3}$ & 0.41 & 0.52 & 0.45 & 0.52 & & & 0.44 & 0.40 & & 0.46 & & \\
\hline $\mathrm{CaO}$ & 40.76 & 41.09 & 41.29 & 40.31 & 41.77 & 41.28 & 42.18 & 41.97 & 41.84 & 41.79 & 42.25 & 40.91 \\
\hline $\mathrm{MnO}$ & 0.26 & 0.22 & 0.24 & 0.31 & 0.23 & 0.26 & 0.23 & 0.42 & 0.39 & 0.28 & 0.24 & 0.22 \\
\hline $\mathrm{SrO}$ & 0.37 & 0.33 & 0.31 & 0.29 & 0.32 & 0.33 & 0.36 & 0.37 & 0.36 & 0.43 & 0.29 & 0.26 \\
\hline $\mathrm{Na}_{2} \mathrm{O}$ & 2.40 & 2.41 & 2.34 & 2.52 & 2.25 & 2.32 & 2.18 & 2.20 & 2.38 & 2.23 & 2.43 & 2.49 \\
\hline $\mathrm{F}$ & 3.72 & 3.89 & 3.91 & 4.24 & 3.98 & 3.77 & 3.71 & 3.84 & 4.08 & 3.82 & 3.43 & 3.53 \\
\hline $\mathrm{H}_{2} \mathrm{O}$ & & & & & & & & & & & 0.06 & 0.00 \\
\hline sum & 100.09 & 100.39 & 100.10 & 99.67 & 99.34 & 100.07 & 100.98 & 99.62 & 100.19 & 100.27 & 100.44 & 99.48 \\
\hline$-\mathrm{O}=\mathrm{F}$ & 1.57 & 1.64 & 1.65 & 1.79 & 1.68 & 1.59 & 1.56 & 1.62 & 1.72 & 1.61 & 1.44 & 1.49 \\
\hline total & 98.52 & 98.75 & 98.45 & 97.88 & 97.66 & 98.48 & 99.42 & 98.00 & 98.47 & 98.66 & 99.00 & 98.00 \\
\hline \multirow[t]{2}{*}{$\mathrm{REE}_{2} \mathrm{O}_{3}$} & 15.50 & 15.50 & 15.14 & 16.62 & 14.06 & 14.88 & 14.62 & 13.58 & 14.21 & 14.50 & 14.75 & 15.47 \\
\hline & \multicolumn{12}{|c|}{ Cations per formula unit on the basis of 13 oxygens } \\
\hline $\mathrm{P}$ & 2.752 & 2.721 & 2.713 & 2.632 & 2.711 & 2.743 & 2.760 & 2.750 & 2.716 & 2.739 & 2.742 & 2.720 \\
\hline $\mathrm{Si}$ & 0.071 & 0.083 & 0.089 & 0.099 & 0.083 & 0.081 & 0.070 & 0.066 & 0.068 & 0.076 & 0.068 & 0.100 \\
\hline $\mathrm{Y}$ & 0.022 & 0.024 & 0.019 & 0.021 & 0.020 & 0.019 & 0.016 & 0.021 & 0.020 & 0.017 & 0.020 & 0.020 \\
\hline $\mathrm{La}$ & 0.092 & 0.090 & 0.091 & 0.100 & 0.088 & 0.089 & 0.082 & 0.082 & 0.088 & 0.083 & 0.097 & 0.103 \\
\hline $\mathrm{Ce}$ & 0.216 & 0.228 & 0.229 & 0.246 & 0.216 & 0.220 & 0.209 & 0.200 & 0.214 & 0.215 & 0.232 & 0.242 \\
\hline $\operatorname{Pr}$ & 0.030 & 0.026 & 0.029 & 0.034 & 0.030 & 0.033 & 0.026 & 0.031 & 0.015 & 0.026 & 0.018 & 0.026 \\
\hline $\mathrm{Nd}$ & 0.117 & 0.115 & 0.103 & 0.125 & 0.110 & 0.111 & 0.103 & 0.100 & 0.109 & 0.103 & 0.119 & 0.125 \\
\hline $\mathrm{Sm}$ & 0.021 & 0.011 & 0.013 & 0.012 & & 0.016 & 0.023 & & 0.018 & 0.016 & & \\
\hline $\mathrm{Gd}$ & 0.012 & 0.015 & 0.013 & 0.016 & & & 0.013 & 0.012 & & 0.014 & & \\
\hline $\mathrm{Ca}$ & 3.912 & 3.928 & 3.952 & 3.916 & 4.003 & 3.946 & 3.992 & 4.002 & 3.978 & 3.982 & 4.047 & 3.966 \\
\hline $\mathrm{Mn}$ & 0.020 & 0.017 & 0.018 & 0.024 & 0.017 & 0.020 & 0.017 & 0.032 & 0.029 & 0.021 & 0.018 & 0.017 \\
\hline $\mathrm{Sr}$ & 0.019 & 0.017 & 0.016 & 0.015 & 0.017 & 0.017 & 0.018 & 0.019 & 0.019 & 0.022 & 0.015 & 0.014 \\
\hline $\mathrm{Na}$ & 0.417 & 0.417 & 0.405 & 0.443 & 0.390 & 0.401 & 0.373 & 0.380 & 0.409 & 0.385 & 0.420 & 0.436 \\
\hline $\mathrm{F}$ & 1.054 & 1.098 & 1.105 & 1.216 & 1.126 & 1.064 & 1.036 & 1.081 & 1.145 & 1.075 & 0.970 & 1.010 \\
\hline $\mathrm{OH}$ & & & & & & & & & & & 0.036 & 0.000 \\
\hline Total cations & 7.701 & 7.692 & 7.691 & 7.682 & 7.687 & 7.697 & 7.704 & 7.695 & 7.684 & 7.698 & 7.797 & 7.770 \\
\hline REE & 0.510 & 0.509 & 0.497 & 0.553 & 0.465 & 0.489 & 0.473 & 0.446 & 0.465 & 0.473 & 0.486 & 0.516 \\
\hline
\end{tabular}

Notes: Blank = below EMP detection limit. All analyses of As, Dy, Ho, Er, Yb, Th, U, S and Cl are below detection limit and therefore not included in the table. 


\begin{tabular}{|c|c|c|c|c|c|c|c|c|c|c|c|c|c|c|}
\hline \multirow{2}{*}{$\frac{\text { Region of crystal }}{\text { Analysis }}$} & \multicolumn{14}{|c|}{$\begin{array}{l}\text { Individual pristine grain of fluorapatite } \\
\text { Dark domains }\end{array}$} \\
\hline & 2 & 4 & 5 & 11 & 12 & 13 & 33 & 38 & 104 & 106 & 107 & 108 & 109 & 111 \\
\hline $\mathrm{P}_{2} \mathrm{O}_{5}$ & 37.47 & 38.01 & 37.54 & 37.73 & 37.00 & 37.14 & 36.63 & 37.68 & 37.45 & 37.51 & 36.73 & 37.33 & 37.06 & 37.04 \\
\hline $\mathrm{SiO}_{2}$ & 0.92 & 0.89 & 0.96 & 0.98 & 1.07 & 0.92 & 1.05 & 0.92 & 0.96 & 0.80 & 1.15 & 0.93 & 1.12 & 1.18 \\
\hline $\mathrm{Y}_{2} \mathrm{O}_{3}$ & 0.23 & 0.31 & 0.27 & 0.26 & 0.33 & 0.29 & 0.31 & 0.36 & 0.31 & 0.30 & 0.31 & 0.27 & 0.30 & 0.30 \\
\hline $\mathrm{La}_{2} \mathrm{O}_{3}$ & 1.85 & 1.84 & 1.99 & 2.07 & 2.11 & 1.95 & 2.07 & 2.03 & 1.98 & 2.04 & 2.28 & 1.99 & 2.36 & 2.39 \\
\hline $\mathrm{Ce}_{2} \mathrm{O}_{3}$ & 5.02 & 5.08 & 4.86 & 5.19 & 5.34 & 5.03 & 5.23 & 4.85 & 5.15 & 5.15 & 5.93 & 5.15 & 5.49 & 5.80 \\
\hline $\mathrm{Pr}_{2} \mathrm{O}_{3}$ & 0.68 & 0.69 & 0.68 & 0.59 & 0.64 & 0.78 & 0.73 & 0.84 & 0.74 & 0.63 & 0.81 & 0.67 & 0.73 & 0.60 \\
\hline $\mathrm{Nd}_{2} \mathrm{O}_{3}$ & 2.60 & 2.37 & 2.62 & 2.63 & 2.63 & 2.53 & 2.59 & 2.38 & 2.39 & 2.50 & 3.13 & 2.85 & 3.06 & 3.20 \\
\hline $\mathrm{Sm}_{2} \mathrm{O}_{3}$ & 0.49 & 0.39 & 0.39 & 0.41 & 0.41 & 0.49 & 0.51 & 0.48 & & & & 0.61 & & \\
\hline $\mathrm{Gd}_{2} \mathrm{O}_{3}$ & & & & & & & & & & 0.50 & & & & \\
\hline $\mathrm{CaO}$ & 45.32 & 45.24 & 45.84 & 45.06 & 44.94 & 45.11 & 44.97 & 45.61 & 46.17 & 45.94 & 44.51 & 45.68 & 45.12 & 44.80 \\
\hline $\mathrm{MnO}$ & 0.25 & 0.32 & 0.13 & 0.23 & 0.28 & 0.16 & 0.17 & 0.16 & 0.22 & 0.18 & 0.22 & 0.27 & 0.19 & 0.29 \\
\hline $\mathrm{SrO}$ & 0.31 & 0.38 & 0.32 & 0.33 & 0.33 & 0.31 & 0.30 & 0.32 & 0.29 & 0.23 & 0.22 & 0.30 & 0.28 & 0.26 \\
\hline $\mathrm{Na}_{2} \mathrm{O}$ & 1.57 & 1.65 & 1.57 & 1.71 & 1.67 & 1.66 & 1.65 & 1.57 & 1.66 & 1.70 & 1.76 & 1.67 & 1.79 & 1.75 \\
\hline F & 3.83 & 3.78 & 3.93 & 3.82 & 3.94 & 3.93 & 4.00 & 3.82 & 3.65 & 3.29 & 3.53 & 3.35 & 2.89 & 3.58 \\
\hline $\mathrm{H}_{2} \mathrm{O}$ & & & & & & & & & 0.00 & 0.16 & 0.05 & 0.14 & 0.35 & 0.03 \\
\hline sum & 100.54 & 100.95 & 101.10 & 101.01 & 100.69 & 100.30 & 100.21 & 101.02 & 100.95 & 100.91 & 100.62 & 101.22 & 100.74 & 101.21 \\
\hline$-\mathrm{O}=\mathrm{F}$ & 1.61 & 1.59 & 1.65 & 1.61 & 1.66 & 1.65 & 1.68 & 1.61 & 1.54 & 1.39 & 1.49 & 1.41 & 1.21 & 1.51 \\
\hline total & 98.93 & 99.36 & 99.45 & 99.40 & 99.03 & 98.65 & 98.53 & 99.41 & 99.42 & 99.52 & 99.14 & 99.80 & 99.52 & 99.71 \\
\hline \multirow[t]{2}{*}{$\mathrm{REE}_{2} \mathrm{O}_{3}$} & 10.9 & 10.7 & 10.8 & 11.2 & 11.5 & 11.1 & 11.4 & 10.9 & 10.56 & 11.11 & 12.46 & 11.54 & 11.93 & 12.29 \\
\hline & \multicolumn{14}{|c|}{ Cations per formula unit on the basis of 13 oxygens } \\
\hline$P$ & 2.755 & 2.777 & 2.742 & 2.762 & 2.725 & 2.739 & 2.711 & 2.757 & 2.748 & 2.767 & 2.733 & 2.753 & 2.756 & 2.735 \\
\hline $\mathrm{Si}$ & 0.080 & 0.077 & 0.083 & 0.085 & 0.093 & 0.080 & 0.092 & 0.080 & 0.083 & 0.070 & 0.101 & 0.081 & 0.098 & 0.103 \\
\hline Y & 0.011 & 0.014 & 0.012 & 0.012 & 0.015 & 0.013 & 0.014 & 0.017 & 0.014 & 0.014 & 0.014 & \begin{tabular}{|l}
0.013 \\
\end{tabular} & 0.014 & 0.014 \\
\hline $\mathrm{La}$ & 59 & 0.059 & 0.063 & 0.066 & 0.068 & 0.063 & 0.067 & 0.065 & 0.063 & 0.065 & 0.074 & 0.064 & 0.076 & 0.077 \\
\hline $\mathrm{Ce}$ & 0.160 & 0.160 & 0.153 & 0.164 & 0.170 & 0.160 & 0.167 & 0.153 & 0.163 & 0.164 & 0.191 & 0.164 & 0.177 & 0.185 \\
\hline $\operatorname{Pr}$ & 0.022 & 0.022 & 0.021 & 0.019 & 0.020 & 0.025 & 0.023 & 0.026 & 0.023 & 0.020 & 0.026 & \begin{tabular}{|l}
0.021 \\
\end{tabular} & 0.023 & 0.019 \\
\hline $\mathrm{Nd}$ & 0.081 & 0.073 & 0.081 & 0.081 & 0.082 & 0.079 & 0.081 & 0.073 & 0.074 & 0.078 & 0.098 & \begin{tabular}{|l}
0.089 \\
\end{tabular} & 0.096 & 0.100 \\
\hline $\mathrm{Sm}$ & 0.015 & 0.012 & 0.012 & 0.012 & 0.012 & 0.015 & 0.015 & 0.014 & & & & 0.018 & & \\
\hline $\mathrm{Gd}$ & & & & & & & & & & 0.014 & & & & \\
\hline $\mathrm{Ca}$ & 4.216 & 4.183 & 4.237 & 4.174 & 4.188 & 4.210 & 4.212 & 4.223 & 4.287 & 4.289 & 4.190 & 4.263 & 4.247 & 4.186 \\
\hline Mn & 0.018 & 0.023 & 0.009 & 0.017 & 0.021 & 0.012 & 0.013 & 0.012 & 0.016 & 0.013 & 0.017 & 0.020 & 0.014 & 0.021 \\
\hline $\mathrm{Sr}$ & 0.016 & 0.019 & 0.016 & 0.017 & 0.017 & 0.016 & 0.015 & 0.016 & 0.015 & 0.012 & 0.011 & 0.015 & 0.014 & 0.013 \\
\hline $\mathrm{Na}$ & 0.264 & 0.276 & 0.263 & 0.287 & 0.282 & 0.280 & 0.280 & 0.263 & 0.278 & 0.287 & 0.299 & 0.281 & 0.306 & 0.297 \\
\hline $\mathrm{F}$ & 1.052 & 1.032 & 1.072 & 1.045 & 1.084 & 1.083 & 1.106 & 1.044 & 1.000 & 0.907 & 0.980 & 0.924 & 0.802 & 0.988 \\
\hline $\mathrm{OH}$ & & & & & & & & & 0.000 & 0.093 & 0.029 & 0.081 & 0.205 & 0.017 \\
\hline Total cations & 7.695 & 7.694 & 7.692 & 7.694 & 7.693 & 7.692 & 7.691 & 7.699 & 7.765 & 7.792 & 7.753 & 7.782 & 7.822 & 7.749 \\
\hline REE & 0.346 & 0.340 & 0.343 & 0.354 & 0.367 & 0.355 & 0.368 & 0.349 & 0.338 & 0.355 & 0.403 & 0.369 & 0.386 & 0.395 \\
\hline
\end{tabular}

Notes: Blank = below EMP detection limit. All analyses of As, Dy, Ho, Er, Yb, Th, U, S and Cl are below detection limit and therefore not included in the table.

Table 3B. Representative electron microprobe analyses of the fluorapatite

in the concentrations of $\mathrm{Ca}$ and $\mathrm{Si}$. Lower contents of 8.0-9.5 wt.\% $\mathrm{CaO}$ and $18.0-18.5 \mathrm{SiO}_{2}$ are found in the bright domains, and higher content of 9.9-11.3 wt.\% $\mathrm{CaO}$ and $18.6-19.7$ wt.\% $\mathrm{SiO}_{2}$ in the dark domains.

The compositions of the dark and bright domains in the fluorapatite associated with fluorbritholite-(Ce) vary strongly. These variations include $2.2-2.5$ wt. $\%$ $\mathrm{SiO}_{2}$ in dark domains vs. $2.4-4.0$ wt. $\% \mathrm{SiO}_{2}$ in bright domains, 34.5-35.8 wt. $\% \mathrm{P}_{2} \mathrm{O}_{5}$ in dark domains vs.
31.2-33.0 wt. $\% \mathrm{P}_{2} \mathrm{O}_{5}$ in bright domains, and 13.2-15.1 wt. $\% \mathrm{REE}_{2} \mathrm{O}_{3}$ in dark domains vs. 17.1-19.1 wt.\% $\mathrm{REE}_{2} \mathrm{O}_{3}$ in bright domains. Compared to individual grains of fluorapatite, the fluorapatite associated with fluorbritholite-(Ce) has higher contents of $\mathrm{Si}, \mathrm{Sr}, \mathrm{Y}$ and LREE, and lower contents of $\mathrm{Ca}, \mathrm{F}$ and HREE (Textfig. 6).

The monazite composition is typical of monazite-(Ce), although there are variable $\mathrm{La}$ and $\mathrm{Nd}$ contents $(0.38$ to $0.93 \mathrm{Nd} / \mathrm{La}$; Table 5$)$. The monazite 
STABILITY RELATIONSHIPS OF REE-BEARING PHOSPHATES IN AN ALKALI-RICH SYSTEM

\begin{tabular}{|c|c|c|c|c|c|c|c|c|c|c|c|c|}
\hline \multirow{3}{*}{$\begin{array}{l}\text { Region of crystal } \\
\text { Analysis }\end{array}$} & \multicolumn{6}{|c|}{ Fluorapatite associated with fluorbritholite } & & & & & & \\
\hline & \multicolumn{6}{|c|}{ Bright domains } & \multicolumn{6}{|c|}{ Dark domains } \\
\hline & 101 & 103 & 107 & 108 & 110 & 112 & 102 & 104 & 105 & 106 & 109 & 111 \\
\hline $\mathrm{P}_{2} \mathrm{O}_{5}$ & 31.21 & 31.82 & 31.69 & 32.78 & 31.60 & 32.99 & 34.86 & 35.75 & 34.67 & 34.82 & 34.51 & 35.30 \\
\hline $\mathrm{SiO}_{2}$ & 3.81 & 3.83 & 3.82 & 3.38 & 3.99 & 2.44 & 2.27 & 2.51 & 2.16 & 2.36 & 2.31 & 2.19 \\
\hline $\mathrm{Y}_{2} \mathrm{O}_{3}$ & 1.19 & 0.87 & 0.96 & 0.67 & 1.28 & 0.83 & 0.57 & 0.71 & 0.52 & 0.56 & 0.57 & 0.85 \\
\hline $\mathrm{La}_{2} \mathrm{O}_{3}$ & 3.17 & 3.23 & 3.43 & 3.39 & 3.27 & 3.99 & 2.69 & 2.82 & 2.89 & 2.88 & 2.93 & 2.31 \\
\hline $\mathrm{Ce}_{2} \mathrm{O}_{3}$ & 7.84 & 8.68 & 8.43 & 8.61 & 7.68 & 8.80 & 6.47 & 7.03 & 7.31 & 6.83 & 6.94 & 6.09 \\
\hline $\mathrm{Pr}_{2} \mathrm{O}_{3}$ & 1.09 & 1.28 & 0.86 & 1.00 & 1.25 & 1.35 & 0.88 & 0.81 & 0.53 & 0.49 & & \\
\hline $\mathrm{Nd}_{2} \mathrm{O}_{3}$ & 3.81 & 4.07 & 4.04 & 4.18 & 4.11 & 4.09 & 3.07 & 3.01 & 3.85 & 3.48 & 3.98 & 3.92 \\
\hline \multirow{2}{*}{\multicolumn{13}{|c|}{$\begin{array}{l}\mathrm{Sm}_{2} \mathrm{O}_{3} \\
\mathrm{Gd}_{2} \mathrm{O}_{3}\end{array}$}} \\
\hline & & & & & & & & & & & & \\
\hline $\mathrm{CaO}$ & 37.91 & 38.46 & 37.57 & 38.63 & 37.45 & 36.29 & 42.32 & 41.33 & 40.36 & 41.65 & 40.69 & 41.52 \\
\hline $\mathrm{MnO}$ & 0.45 & 0.31 & 0.37 & 0.27 & 0.40 & 0.26 & 0.22 & 0.25 & 0.28 & 0.19 & 0.23 & 0.39 \\
\hline $\mathrm{SrO}$ & 0.54 & 0.45 & 0.55 & 0.45 & 0.40 & 0.37 & 0.45 & 0.45 & 0.37 & 0.41 & 0.50 & 0.47 \\
\hline $\mathrm{Na}_{2} \mathrm{O}$ & 1.88 & 1.60 & 1.67 & 1.64 & 1.76 & 2.47 & 1.46 & 1.57 & 1.81 & 1.55 & 1.72 & 1.79 \\
\hline $\mathrm{F}$ & 2.80 & 3.10 & 2.74 & 2.72 & 2.90 & 3.33 & 2.72 & 2.71 & 2.88 & 2.97 & 2.87 & 2.95 \\
\hline $\mathrm{H}_{2} \mathrm{O}$ & 0.25 & 0.14 & 0.28 & 0.32 & 0.21 & 0.00 & 0.36 & 0.40 & 0.27 & 0.25 & 0.28 & 0.26 \\
\hline sum & 95.93 & 97.82 & 96.41 & 98.04 & 96.30 & 97.19 & 98.35 & 99.34 & 97.91 & 98.44 & 97.53 & 98.03 \\
\hline$-\mathrm{O}=\mathrm{F}$ & 1.18 & 1.30 & 1.16 & 1.14 & 1.22 & 1.40 & 1.15 & 1.14 & 1.21 & 1.25 & 1.21 & 1.24 \\
\hline total & 94.75 & 96.52 & 95.25 & 96.89 & 95.08 & 95.79 & 97.20 & 98.20 & 96.70 & 97.19 & 96.32 & 96.79 \\
\hline \multirow[t]{2}{*}{$\mathrm{REE}_{2} \mathrm{O}_{3}$} & 17.09 & 18.13 & 17.71 & 17.84 & 17.58 & 19.05 & 13.68 & 14.38 & 15.11 & 14.24 & 14.41 & 13.17 \\
\hline & \multicolumn{6}{|c|}{ Cations per formula unit on the basis of 13 oxygens } & & & & & & \\
\hline $\mathrm{P}$ & 2.523 & 2.525 & 2.551 & 2.592 & 2.537 & 2.639 & 2.684 & 2.715 & 2.696 & 2.678 & 2.686 & 2.707 \\
\hline $\mathrm{Si}$ & 0.363 & 0.359 & 0.363 & 0.316 & 0.379 & 0.231 & 0.207 & 0.225 & 0.199 & 0.214 & 0.213 & 0.198 \\
\hline Y & 0.060 & 0.044 & 0.048 & 0.033 & 0.064 & 0.041 & 0.028 & 0.034 & 0.026 & 0.027 & 0.028 & 0.041 \\
\hline $\mathrm{La}$ & 0.112 & 0.112 & 0.120 & 0.117 & 0.114 & 0.139 & 0.090 & 0.093 & 0.098 & 0.097 & 0.099 & 0.077 \\
\hline $\mathrm{Ce}$ & 0.274 & 0.298 & 0.293 & 0.294 & 0.267 & 0.304 & 0.215 & 0.231 & 0.246 & 0.227 & 0.233 & 0.202 \\
\hline $\operatorname{Pr}$ & 0.038 & 0.044 & 0.030 & 0.034 & 0.043 & 0.046 & 0.029 & 0.026 & 0.018 & 0.016 & & \\
\hline $\mathrm{Nd}$ & 0.130 & 0.136 & 0.137 & 0.139 & 0.139 & 0.138 & 0.100 & 0.096 & 0.126 & 0.113 & 0.131 & 0.127 \\
\hline \multicolumn{13}{|l|}{$\mathrm{Sm}$} \\
\hline $\mathrm{Gd}$ & & & & & & & & & & & & \\
\hline $\mathrm{Ca}$ & 3.879 & 3.863 & 3.826 & 3.865 & 3.804 & 3.675 & 4.123 & 3.973 & 3.971 & 4.054 & 4.007 & 4.030 \\
\hline $\mathrm{Mn}$ & 0.036 & 0.025 & 0.030 & 0.021 & 0.032 & 0.021 & 0.017 & 0.019 & 0.022 & 0.015 & 0.018 & 0.030 \\
\hline $\mathrm{Sr}$ & 0.030 & 0.024 & 0.030 & 0.025 & 0.022 & 0.020 & 0.024 & 0.023 & 0.020 & 0.021 & 0.027 & 0.025 \\
\hline $\mathrm{Na}$ & 0.348 & 0.290 & 0.308 & 0.296 & 0.324 & 0.453 & 0.258 & 0.273 & 0.322 & 0.272 & 0.306 & 0.314 \\
\hline F & 0.846 & 0.918 & 0.825 & 0.803 & 0.871 & 0.994 & 0.783 & 0.770 & 0.838 & 0.854 & 0.833 & 0.845 \\
\hline $\mathrm{OH}$ & 0.159 & 0.088 & 0.178 & 0.199 & 0.133 & 0.000 & 0.218 & 0.239 & 0.165 & 0.151 & 0.172 & 0.157 \\
\hline Total cations & 7.793 & 7.720 & 7.737 & 7.733 & 7.727 & 7.708 & 7.774 & 7.709 & 7.742 & 7.735 & 7.747 & 7.751 \\
\hline REE & 0.614 & 0.633 & 0.629 & 0.618 & 0.628 & 0.669 & 0.462 & 0.481 & 0.513 & 0.480 & 0.491 & 0.447 \\
\hline
\end{tabular}

Notes: Blank = below EMP detection limit. All analyses of As, $\mathrm{Dy}, \mathrm{Ho}, \mathrm{Er}, \mathrm{Yb}, \mathrm{Th}, \mathrm{U}, \mathrm{S}$ and Cl are below detection limit and therefore not included in the table.

Table 3C. Representative electron microprobe analyses of the fluorapatite

has a low $\mathrm{ThO}_{2}$ content, ranging from 0.5 to 1.6 wt.\%. The concentrations of $\mathrm{U}$ and $\mathrm{Pb}$ are below the detection limit of the electron microprobe. It should be also noted that REEs from $\mathrm{Eu}$ to $\mathrm{Lu}$, except three analytical spots with $0.7-1.0$ wt. $\% \mathrm{Gd}_{2} \mathrm{O}_{3}$, are also below detection limits. Based on the plot of formula proportions $(\mathrm{REE}+\mathrm{P})$ vs. $(\mathrm{Th}+\mathrm{Si})$, substitution of the huttonitic component predominates over substitution of the cheralitic component in the monazite (Text-fig. 7).

\section{DISCUSSION}

The individual matrix grains of fluorapatite in mariupolite are interpreted as primary accessory phases crystallized during the early magmatic stage. The temperature of crystallization can be roughly constrained at ca. $600^{\circ} \mathrm{C}$, with an interval of within $60-100^{\circ} \mathrm{C}$ based on the estimated apatite saturation temperature equation given in Piccoli and Candela (2002). Fluorapatite with extremely high $\mathrm{REE}_{2} \mathrm{O}_{3}$ 


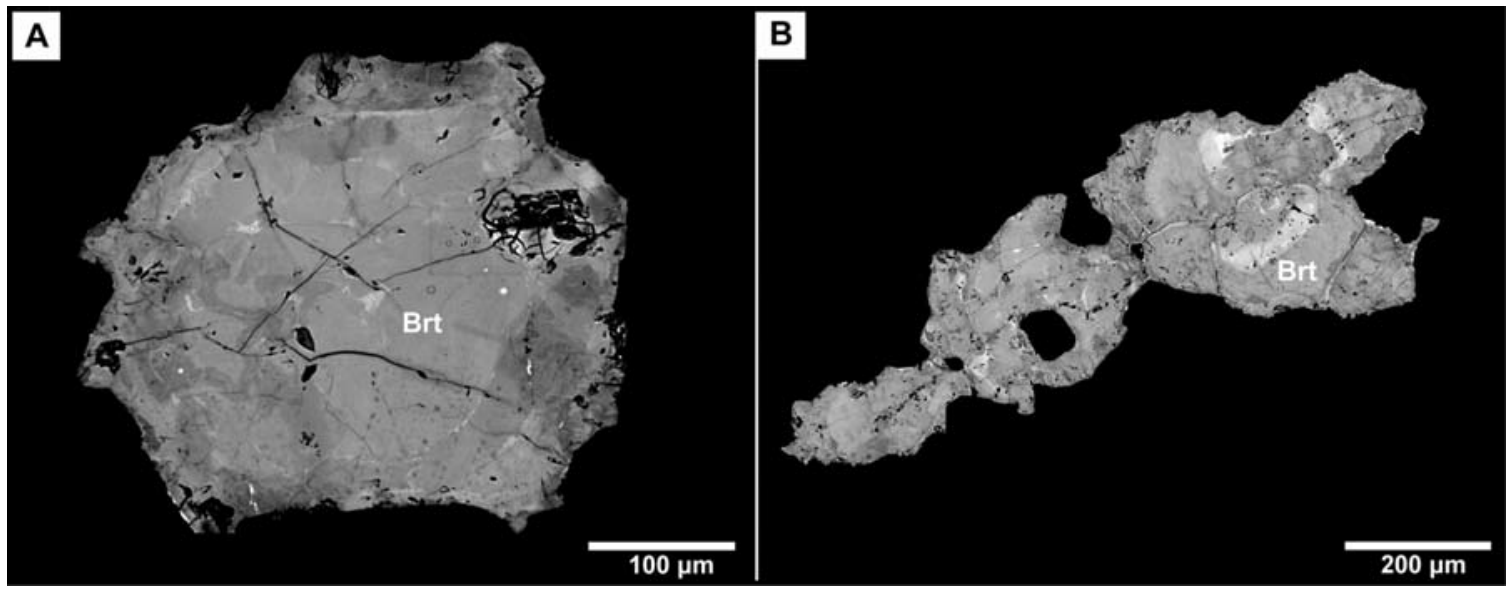

Text-fig. 4. The patchy zoned fluorbritholite-(Ce) (Brt) in high contrast BSE imaging. The internal textures of the grains resulted from the partial alteration of the primary phase via the fluid-aided coupled dissolution-reprecipitation process
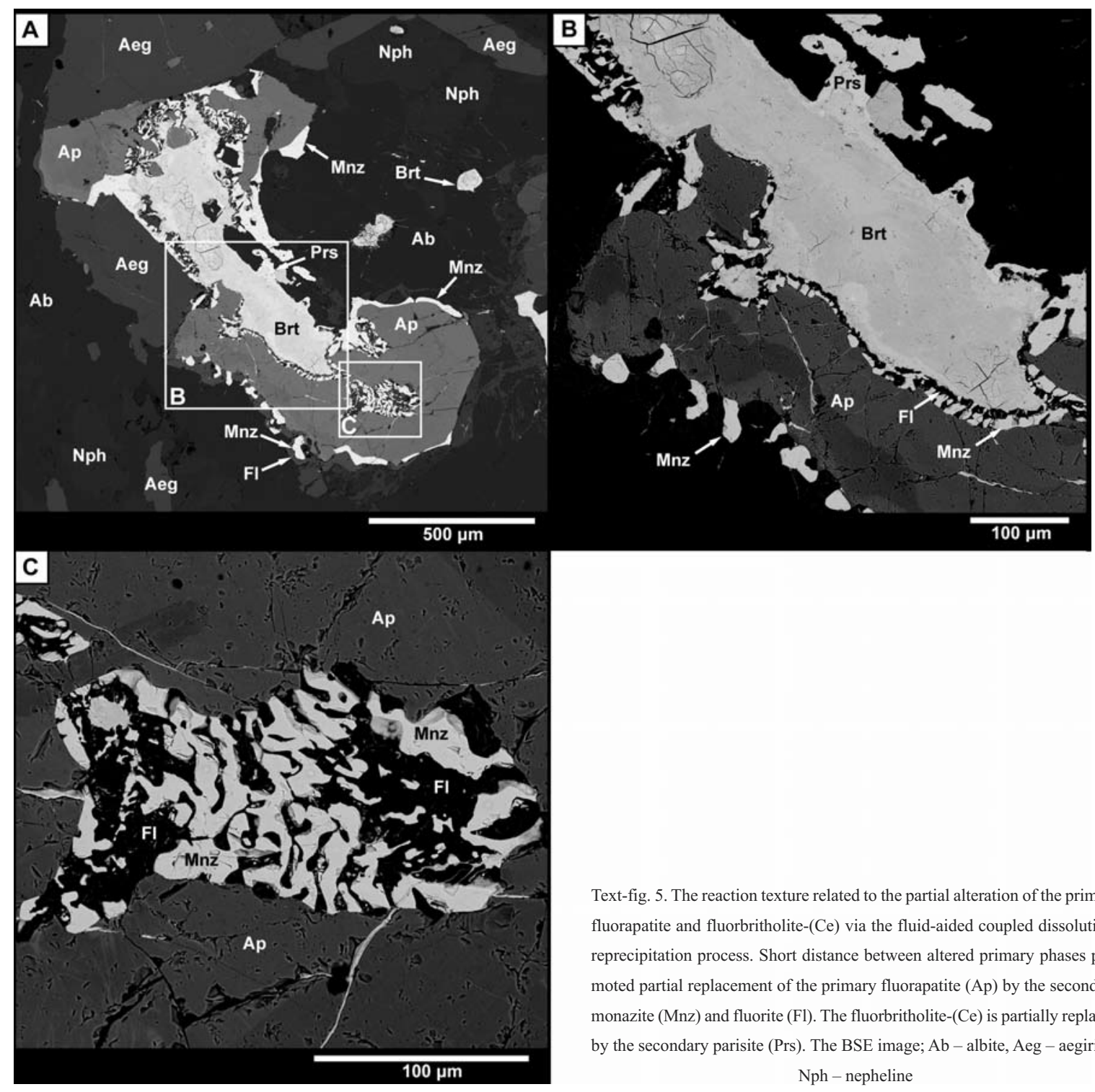

Text-fig. 5. The reaction texture related to the partial alteration of the primary fluorapatite and fluorbritholite-(Ce) via the fluid-aided coupled dissolutionreprecipitation process. Short distance between altered primary phases promoted partial replacement of the primary fluorapatite (Ap) by the secondary monazite (Mnz) and fluorite ( $\mathrm{Fl})$. The fluorbritholite-(Ce) is partially replaced by the secondary parisite (Prs). The BSE image; $\mathrm{Ab}$ - albite, Aeg - aegirine, 
STABILITY RELATIONSHIPS OF REE-BEARING PHOSPHATES IN AN ALKALI-RICH SYSTEM

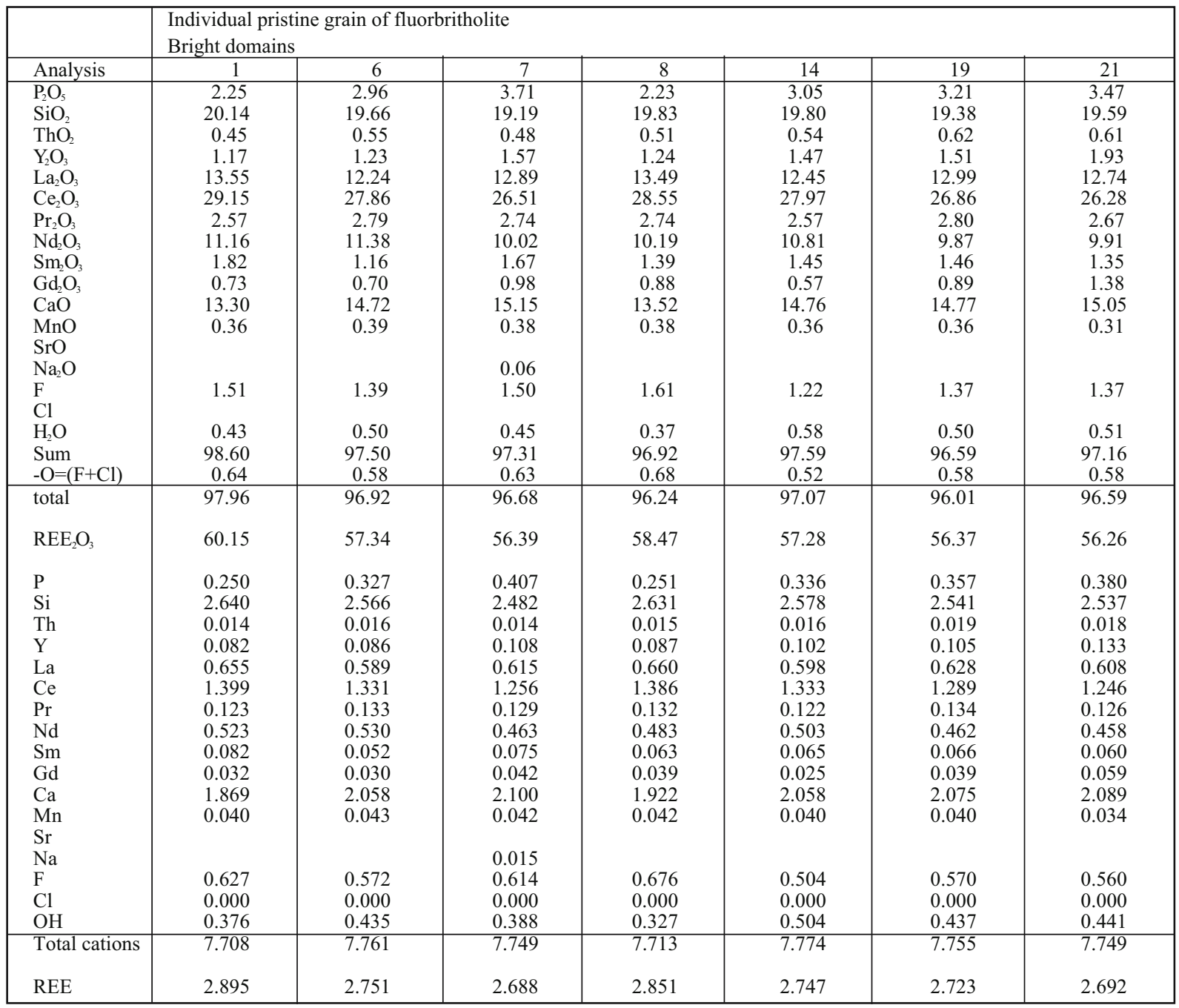

Notes: Blank = below EMP detection limit. All analyses of $\mathrm{Fe}, \mathrm{Dy}, \mathrm{Ho}, \mathrm{Er}, \mathrm{Yb}$, and $\mathrm{U}$ are below detection limit and therefore not included.

Table 4 A. Representative electron microprobe analyses of the fluorbritholite

contents (up to ca. $19 \mathrm{wt} . \%$ ) is strictly related to the open apatite structure and its chemistry that provide the opportunity for various substitutions, resulting in possible incorporation of half the periodic chart in the atomic arrangement (Hughes and Rakovan 2002). The substitution of REEs for Ca in fluorapatite is charge-compensated by $\mathrm{Na}$ and $\mathrm{Si}$ via the coupled substitutions $\mathrm{REE}^{3+}+\mathrm{Si}^{4+}=\mathrm{Ca}^{2+}+\mathrm{P}^{5+}$ and $\mathrm{Na}^{+}+\mathrm{REE}^{3+}=2 \mathrm{Ca}^{2+}$ (cf. Fleet et al. 2000; Pan and Fleet 2002). The bulk rock composition (Table 2) indicates that the melt from which fluorapatite crystallized was a silica-undersaturated (60.2 wt. $\% \mathrm{SiO}_{2}$ with 19.5 wt.\% of nepheline following CIPW norm) and significantly $\mathrm{Na}$-enriched (12.11 wt.\% $\mathrm{Na}_{2} \mathrm{O}$ ) comparing to the low $\mathrm{Ca}$ concentration ( 0.37 wt.\% $\mathrm{CaO})$. A recent experimental study documented monazite dissolution in the presence of a $\left(\mathrm{Na}_{2} \mathrm{Si}_{2} \mathrm{O}_{5}+\right.$
$\mathrm{H}_{2} \mathrm{O}$ ) fluid, and the formation of fluorapatite-britholite solid solution (Budzyń et al. 2011). Experimentally reproduced high $\mathrm{Na}$ activity conditions partially support the interpretation in this study that an alkali-rich system promotes incorporation of REEs into primary igneous fluorapatite and fluorbritholite rather than crystallization of monazite as a primary phosphate REE-host. The light REEs (LREEs) are preferentially substituted into the structure over heavy REEs (HREEs), which are below detection limits of the electron microprobe in both fluorapatite and fluorbritholite-(Ce) (Tables 3, 4). The high LREE/HREE ratio is strictly related to the bulk-rock composition, where LREEs significantly dominate over HREEs (Table 2).

The patchy zoning in both the fluorapatite and fluorbritholite-(Ce) are typical results of metaso- 


\begin{tabular}{|c|c|c|c|c|c|c|c|c|c|c|c|c|}
\hline & Dark do & & & & & & & & & & & \\
\hline Analysis & 2 & 5 & 10 & 11 & 12 & 15 & 16 & 17 & 18 & 20 & 23 & 24 \\
\hline $\mathrm{P}_{2} \mathrm{O}_{5}$ & 4.16 & 3.76 & 4.51 & 4.18 & 4.18 & 4.59 & 5.08 & 4.09 & 4.11 & 4.07 & 4.30 & 4.33 \\
\hline $\mathrm{SiO}_{2}$ & 19.32 & 19.49 & 18.96 & 19.17 & 19.34 & 19.03 & 18.58 & 18.99 & 18.92 & 19.03 & 19.01 & 18.97 \\
\hline $\mathrm{ThO}_{2}$ & 1.21 & 0.90 & 1.18 & 1.09 & 1.20 & 1.35 & 0.77 & 1.13 & 1.15 & 1.23 & 1.35 & 1.47 \\
\hline $\mathrm{Y}_{2} \mathrm{O}_{3}$ & 3.44 & 3.31 & 1.44 & 1.82 & 3.14 & 1.37 & 2.15 & 1.49 & 1.54 & 1.61 & 1.43 & 1.72 \\
\hline $\mathrm{La}_{2} \mathrm{O}_{3}$ & 11.60 & 11.41 & 10.62 & 11.14 & 11.65 & 10.91 & 10.83 & 10.83 & 11.17 & 11.56 & 10.84 & 10.65 \\
\hline $\mathrm{Ce}_{2} \mathrm{O}_{3}$ & 24.39 & 24.62 & 25.43 & 25.61 & 24.84 & 25.65 & 25.16 & 25.94 & 25.67 & 25.62 & 25.92 & 25.80 \\
\hline $\mathrm{Pr}_{2} \mathrm{O}_{3}$ & 2.80 & 1.88 & 2.93 & 2.65 & 2.28 & 2.98 & 2.69 & 3.04 & 2.74 & 3.05 & 2.30 & 2.95 \\
\hline $\mathrm{Nd}_{2} \mathrm{O}_{3}$ & 9.62 & 10.15 & 10.84 & 10.49 & 9.34 & 11.36 & 10.29 & 10.52 & 10.88 & 9.93 & 10.71 & 11.22 \\
\hline $\mathrm{Sm}_{2} \mathrm{O}_{3}$ & 1.34 & 1.81 & 1.86 & 1.40 & 1.37 & 1.47 & 1.55 & 1.35 & 1.74 & 1.68 & 1.22 & 1.58 \\
\hline $\mathrm{Gd}_{2} \mathrm{O}_{3}$ & 0.94 & 1.51 & 0.70 & 1.16 & 1.34 & 0.97 & 0.94 & 0.93 & 1.23 & 0.94 & 0.96 & 1.26 \\
\hline $\mathrm{CaO}$ & 16.02 & 15.78 & 16.28 & 16.24 & 15.94 & 16.40 & 17.26 & 16.15 & 16.00 & 15.87 & 16.41 & 16.43 \\
\hline $\mathrm{MnO}$ & 0.35 & 0.36 & 0.38 & 0.28 & 0.36 & 0.41 & 0.25 & 0.35 & 0.35 & 0.32 & 0.39 & 0.35 \\
\hline $\mathrm{SrO}$ & & & & & & & & & & & & \\
\hline $\begin{array}{l}\mathrm{Na}_{2} \mathrm{O} \\
F\end{array}$ & 150 & 1.27 & 1.80 & 1.42 & 1.42 & $\begin{array}{l}0.07 \\
1.46\end{array}$ & 1.40 & 1.30 & $\begin{array}{l}0.06 \\
1.45\end{array}$ & 1.33 & 1.32 & 1.35 \\
\hline $\mathrm{Cl}$ & & & & & & & & & & & & \\
\hline $\mathrm{H}_{2} \mathrm{O}$ & 0.47 & 0.57 & 0.33 & 0.50 & 0.51 & 0.50 & 0.53 & 0.55 & 0.48 & 0.54 & 0.55 & 0.55 \\
\hline Sum & 97.16 & 96.81 & 97.24 & 97.13 & 96.92 & 98.52 & 97.47 & 96.65 & 97.48 & 96.78 & 96.71 & 98.60 \\
\hline$-\mathrm{O}=(\mathrm{F}+\mathrm{Cl})$ & 0.63 & 0.53 & 0.76 & 0.60 & 0.60 & 0.61 & 0.59 & 0.55 & 0.61 & 0.56 & 0.56 & 0.57 \\
\hline total & 96.53 & 96.27 & 96.49 & 96.53 & 96.33 & 97.91 & 96.88 & 96.11 & 96.87 & 96.22 & 96.15 & 98.03 \\
\hline $\mathrm{REE}_{2} \mathrm{O}_{3}$ & 54.13 & 54.69 & 53.81 & 54.27 & 53.97 & 54.71 & 53.60 & 54.10 & 54.96 & 54.40 & 53.38 & 55.16 \\
\hline $\mathrm{P}$ & 0.448 & 0.409 & 0.485 & 0.453 & 0.452 & 0.491 & 0.543 & 0.447 & 0.448 & 0.446 & 0.468 & 0.466 \\
\hline $\mathrm{Si}$ & 2.458 & 2.506 & 2.411 & 2.455 & 2.468 & 2.406 & 2.347 & 2.455 & 2.433 & 2.459 & 2.443 & 2.412 \\
\hline Th & 0.035 & 0.026 & 0.034 & 0.032 & 0.035 & 0.039 & 0.022 & 0.033 & 0.034 & 0.036 & 0.039 & 0.042 \\
\hline $\mathrm{Y}$ & 0.233 & 0.227 & 0.097 & 0.124 & 0.214 & 0.092 & 0.144 & 0.103 & 0.105 & 0.111 & 0.098 & 0.116 \\
\hline $\mathrm{La}$ & 0.544 & 0.541 & 0.498 & 0.526 & 0.548 & 0.509 & 0.504 & 0.516 & 0.530 & 0.551 & 0.514 & 0.499 \\
\hline $\mathrm{Ce}$ & 1.136 & 1.159 & 1.184 & 1.201 & 1.160 & 1.187 & 1.163 & 1.228 & 1.209 & 1.212 & 1.220 & 1.201 \\
\hline $\operatorname{Pr}$ & 0.130 & 0.088 & 0.136 & 0.124 & 0.106 & 0.137 & 0.124 & 0.143 & 0.128 & 0.143 & 0.107 & 0.136 \\
\hline $\mathrm{Nd}$ & 0.437 & 0.466 & 0.492 & 0.480 & 0.426 & 0.513 & 0.464 & 0.485 & 0.500 & 0.458 & 0.492 & 0.509 \\
\hline $\mathrm{Sm}$ & 0.059 & 0.080 & 0.081 & 0.062 & 0.060 & 0.064 & 0.067 & 0.060 & 0.077 & 0.075 & 0.054 & 0.069 \\
\hline $\mathrm{Gd}$ & 0.039 & 0.064 & 0.029 & 0.049 & 0.057 & 0.041 & 0.039 & 0.040 & 0.053 & 0.040 & 0.041 & 0.053 \\
\hline $\mathrm{Ca}$ & 2.184 & 2.174 & 2.217 & 2.228 & 2.180 & 2.221 & 2.335 & 2.236 & 2.204 & 2.197 & 2.260 & 2.237 \\
\hline $\mathrm{Mn}$ & 0.038 & 0.039 & 0.041 & 0.030 & 0.039 & 0.044 & 0.027 & 0.038 & 0.038 & 0.034 & 0.042 & 0.038 \\
\hline $\mathrm{Sr}$ & & & & & & & & & & & & \\
\hline $\mathrm{Na}$ & & & & & & 0.017 & & & 0.016 & & & \\
\hline $\mathrm{F}$ & 0.604 & 0.516 & 0.723 & 0.575 & 0.571 & 0.582 & 0.560 & 0.530 & 0.590 & 0.544 & 0.537 & 0.544 \\
\hline $\mathrm{Cl}$ & 0.000 & 0.000 & 0.000 & 0.000 & 0.000 & 0.000 & 0.000 & 0.000 & 0.000 & 0.000 & 0.000 & 0.000 \\
\hline $\mathrm{OH}$ & 0.399 & 0.489 & 0.280 & 0.427 & 0.434 & 0.422 & 0.446 & 0.474 & 0.412 & 0.466 & 0.472 & 0.466 \\
\hline Total cations & 7.742 & 7.780 & 7.705 & 7.762 & 7.745 & 7.762 & 7.780 & 7.786 & 7.773 & 7.764 & 7.780 & 7.779 \\
\hline REE & 2.579 & 2.626 & 2.517 & 2.565 & 2.571 & 2.543 & 2.506 & 2.575 & 2601 & 2.591 & 2.526 & 2.584 \\
\hline
\end{tabular}

Notes: Blank = below EMP detection limit. All analyses of $\mathrm{Fe}, \mathrm{Dy}, \mathrm{Ho}, \mathrm{Er}, \mathrm{Yb}$, and $\mathrm{U}$ are below detection limit and therefore not included.

Table 4 B. Representative electron microprobe analyses of the fluorbritholite

matic alteration leading to partial replacement via fluid-mediated coupled dissolution-reprecipitation (e.g. Putnis 2002, 2009). The reactive fluid generally operates as a catalyst, leading to the replacement of a mineral phase by a new composition of the same phase or by a completely new phase (Harlov et al. 2011). Chemical alteration via fluid-aided dissolution-reprecipitation may lead to the formation of various textures, including patchy zoning, but also concentric zoning that may be interpreted as a typical growth texture instead of a result of partial replacement (cf. Hetherington et al. 2010; Budzyń et al. 2011; Harlov et al. 2011; Williams et al. 2011). The process requires the same rates of dissolution of the primary phase and reprecipitation of the altered (or new) phase, which are in direct contact, separated only by a thin fluid film operating at a submicron scale to transport material across the reaction front (Harlov et al. 2011).

The fluorapatite showing patchy zoning and overgrowth-like rims that are bright in BSE images (Textfig. 2c) is interpreted as a primary igneous phase metasomatically altered via fluid-aided dissolutionreprecipitation. There is no doubt that the patchy zoning is the result of such a process. Although bright rims potentially may be overgrowths, the partial penetration into the grain cores along the patches borders and the presence of secondary parisite inclusions indicate that the rims were also formed by the chemical alteration of fluorapatite. The high-Na bulk composition promoted the REEs transported across fluid front penetrating fluorapatite to be incorporated into the structure via the substitution $\mathrm{Na}^{+}+\mathrm{REE}^{3+}=2 \mathrm{Ca}^{2+}$. The $\mathrm{Ca}$ (and F) released from the altered fluorapatite formed parisite 
STABILITY RELATIONSHIPS OF REE-BEARING PHOSPHATES IN AN ALKALI-RICH SYSTEM

\begin{tabular}{|c|c|c|c|c|c|c|c|c|c|c|c|c|}
\hline & \multicolumn{12}{|c|}{$\begin{array}{l}\text { Fluorbritholite associated with fluorapatite } \\
\text { Dark domains }\end{array}$} \\
\hline Analysis & 1 & 2 & 6 & 10 & 11 & 12 & 3 & 4 & 5 & 7 & 8 & 9 \\
\hline $\mathrm{P}_{2} \mathrm{O}_{5}$ & 1.79 & 1.80 & 2.66 & 2.21 & 1.80 & 1.78 & 2.21 & 2.71 & 2.53 & 3.20 & 3.35 & 2.62 \\
\hline $\mathrm{SiO}_{2}$ & 19.24 & 19.57 & 18.61 & 19.69 & 19.51 & 19.60 & 18.50 & 18.37 & 18.41 & 17.99 & 18.46 & 18.24 \\
\hline $\mathrm{ThO}_{2}$ & 0.86 & 1.03 & 0.82 & 0.83 & 0.84 & 0.77 & 1.01 & 0.91 & 0.98 & 0.94 & 1.00 & 1.05 \\
\hline $\mathrm{Y}_{2} \mathrm{O}_{3}$ & 1.63 & 1.66 & 1.48 & 1.41 & 1.68 & 1.66 & 1.81 & 1.61 & 1.50 & 1.66 & 1.54 & 1.65 \\
\hline $\mathrm{La}_{2} \mathrm{O}_{3}$ & 12.92 & 12.93 & 12.13 & 12.65 & 13.08 & 12.96 & 12.82 & 11.94 & 12.16 & 12.22 & 12.29 & 13.15 \\
\hline $\mathrm{Ce}_{2} \mathrm{O}_{3}$ & 27.86 & 27.97 & 27.77 & 28.43 & 27.72 & 27.94 & 28.07 & 28.85 & 28.32 & 28.15 & 27.92 & 27.80 \\
\hline $\mathrm{Pr}_{2} \mathrm{O}_{3}$ & 3.03 & 2.82 & 3.07 & 2.54 & 2.39 & 2.60 & 2.83 & 2.39 & 2.93 & 2.90 & 2.86 & 2.54 \\
\hline $\mathrm{Nd}_{2} \mathrm{O}_{3}$ & 10.65 & 10.47 & 11.58 & 11.15 & 10.90 & 10.88 & 11.85 & 11.70 & 11.49 & 12.23 & 11.29 & 11.28 \\
\hline $\mathrm{Sm}_{2} \mathrm{O}_{3}$ & 1.61 & 1.67 & 1.54 & 1.58 & 1.74 & 1.55 & 1.72 & 1.72 & 1.21 & 1.51 & 1.69 & 1.16 \\
\hline $\mathrm{Gd}_{2} \mathrm{O}_{3}$ & 1.19 & 1.06 & 1.01 & 0.86 & 1.43 & 1.16 & 1.08 & 1.23 & 0.65 & 1.02 & 1.63 & 1.25 \\
\hline $\mathrm{CaO}$ & 10.68 & 10.75 & 11.33 & 11.37 & 9.98 & 10.07 & 7.97 & 9.04 & 9.24 & 9.10 & 9.53 & 8.46 \\
\hline $\mathrm{MnO}$ & 0.52 & 0.50 & 0.60 & 0.60 & 0.68 & 0.72 & 0.59 & 0.64 & 0.62 & 0.51 & 0.59 & 0.52 \\
\hline $\mathrm{SrO}$ & & 0.13 & 0.07 & 0.12 & 0.13 & 0.12 & & 0.15 & 0.08 & & & 0.07 \\
\hline $\mathrm{NaO}$ & 0.42 & 0.41 & 0.32 & 0.33 & 0.51 & 0.46 & 0.74 & 0.45 & 0.63 & 0.53 & 0.51 & 0.54 \\
\hline $\mathrm{F}$ & 2.36 & 2.18 & 1.95 & 1.48 & 2.09 & 2.31 & 1.68 & 1.35 & 1.79 & 1.40 & 1.50 & 1.56 \\
\hline $\mathrm{Cl}$ & & & 0.06 & & & & 0.07 & & 0.07 & 0.07 & & \\
\hline $\mathrm{H}_{2} \mathrm{O}$ & 0.00 & 0.00 & 0.00 & 0.00 & 0.00 & 0.00 & 0.00 & 0.00 & 0.00 & 0.00 & 0.00 & 0.00 \\
\hline Sum & 94.75 & 94.95 & 95.01 & 95.23 & 94.48 & 94.56 & 92.96 & 93.05 & 92.59 & 93.42 & 94.17 & 91.88 \\
\hline$-\mathrm{O}=(\mathrm{F}+\mathrm{Cl})$ & 0.99 & 0.92 & 0.83 & 0.63 & 0.88 & 0.97 & 0.72 & 0.57 & 0.77 & 0.60 & 0.63 & 0.66 \\
\hline total & 93.76 & 94.03 & 94.17 & 94.60 & 93.60 & 93.59 & 92.24 & 92.48 & 91.83 & 92.82 & 93.54 & 91.22 \\
\hline $\mathrm{REE}_{2} \mathrm{O}_{3}$ & 58.88 & 58.58 & 58.58 & 58.62 & 58.94 & 58.73 & 60.19 & 59.43 & 58.26 & 59.69 & 59.23 & 58.83 \\
\hline
\end{tabular}

Notes: Blank = below EMP detection limit. All analyses of $\mathrm{Fe}, \mathrm{Dy}, \mathrm{Ho}, \mathrm{Er}, \mathrm{Yb}$ and $\mathrm{U}$ are below detection limit and therefore not included.

Table 4 C. Representative electron microprobe analyses of the fluorbritholite

inclusion, which points to the presence of a $\mathrm{CO}_{2}$ component in the reactive fluid. The source of REEs was probably the fluorbritholite-(Ce) that also shows patchy zoning, although the brighter domains concentrate near the cores, whilst darker domains, interpreted as chemically altered, are present near the rims. The reactive fluid penetrating the primary igneous britholite(Ce) released REEs that were mobilized and incorporated into the altered fluorapatite. REEs mobility was induced by a fluid with a high $\mathrm{F}$ activity (cf. Pan and Fleet 1996; Tropper and Manning 2007).

The progress of the alteration differed significantly, depending on the distance between the fluorapatite and fluorbritholite-(Ce) grains in the host mariupolite. The close proximity of fluorbritholite-(Ce) resulted in the fluid-aided dissolution-reprecipitation replacement of the altered fluorapatite by secondary monazite and fluorite that form symplectite-like grains surrounding, and present within, the fluorapatite. The altered fluorbritholite-(Ce) was a source of REEs that were mobilized and transported over a short distance to the altered fluorapatite to form monazite. Mobilization of $\mathrm{PO}_{4}{ }^{3-}$ anions from the fluorapatite in the presence of $\mathrm{F}$ rich fluid followed, with mobilization of $\mathrm{Ca}^{2+}$ to form fluorite. Additionally, the altered domains in fluorbritholite-(Ce) contain parisite inclusions, suggesting a $\mathrm{CO}_{2}$ component in the reactive fluid that facilitated chemical alteration.

There is no direct evidence as to the precise conditions of fluorapatite and fluorbritholite-(Ce) alteration. The presence of secondary monazite with a low
Th content may suggest low temperature conditions, according to the previous work that has documented very low Th contents in monazite formed during lowgrade metamorphism (Rasmussen and Muhling 2009) or hydrothermal events (Kempe et al. 2008). However, the Th concentration in the monazite is also controlled by the Th budget in the bulk composition during monazite crystallization. Here, the $\mathrm{ThO}_{2}$ content in monazite $(0.5-1.2$ wt.\%) is similar to that in the fluorbritholite-(Ce) (0.5-1.5 wt.\%), and there is no other potential source among the primary mineral phases.

A recent experimental study on the stability relationships between monazite, fluorapatite, allanite and REE-epidote (Budzyń et al. 2011), even though it concerned a silica-saturated system, may be a reference point in this discussion. The experimental results from runs with $\mathrm{NaOH}$ (alkaline) fluid showed that starting monazite is dissolved to form secondary monazite and fluorapatite-britholite at lower P-T conditions $\left(450^{\circ} \mathrm{C}\right.$, $450 \mathrm{MPa}$ ), while increasing $\mathrm{P}$ or $\mathrm{T}$ promotes dissolution of monazite to form secondary fluorapatite $\left(500^{\circ} \mathrm{C}, 450 \mathrm{MPa}\right)$ or fluorapatite-britholite phase and allanite $\left(450^{\circ} \mathrm{C}, 610-580 \mathrm{MPa}\right)$ (Budzyń et al. 2011). Because the Ca activity plays a significant role in the stability relations of monazite, allanite and fluorapatite in granitic rocks (Lee and Dodge 1964; Lee and Bastron 1967; Bea 1996; Broska et al. 2000; Claeson 2002), it is unexpected that allanite or REE-epidote would form in the mariupolite, which has a low $\mathrm{Ca}$ content. Rather, high temperature conditions promoted crystallization of primary REE-enriched fluorapatite 

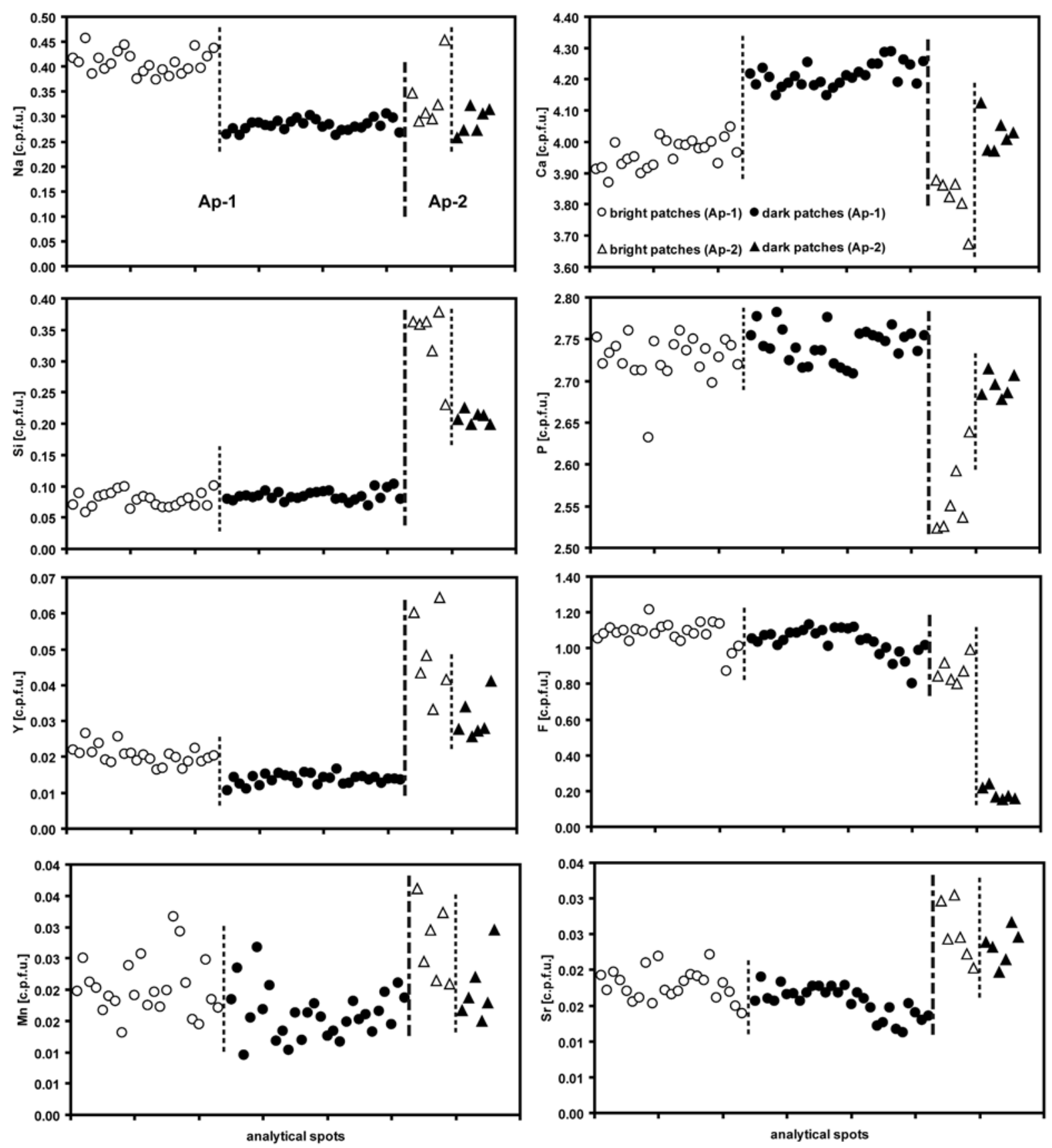

Text-fig. 6 A. Plots showing compositional variations between dark and bright domains in (Ap-1) the fluorapatite present as individual grains; and (Ap-2) the fluorapatite in contact with the fluorbritholite shown in Figure 5. The cations are calculated on the basis of $13 \mathrm{O}$ atoms

and fluorbritholite from the parent magma, whilst lateto post-magmatic metasomatic alteration promoted formation of monazite stable under low-temperature conditions.

\section{CONCLUSIONS}

The mechanism of the fluid-mediated coupled dissolution-reprecipitation that promoted alteration of the primary igneous fluorapatite and fluorbritholite-(Ce) in the mariupolite significantly depended on the distance between the phases in the host rock. The altered domains in the individual fluorapatite or fluorbritholite-(Ce) grains were replaced by the same phases with a new composition. The REEs were mobilized from the altered fluorbritholite-(Ce) and transported by a fluid with high $\mathrm{F}$ activity. The 
STABILITY RELATIONSHIPS OF REE-BEARING PHOSPHATES IN AN ALKALI-RICH SYSTEM
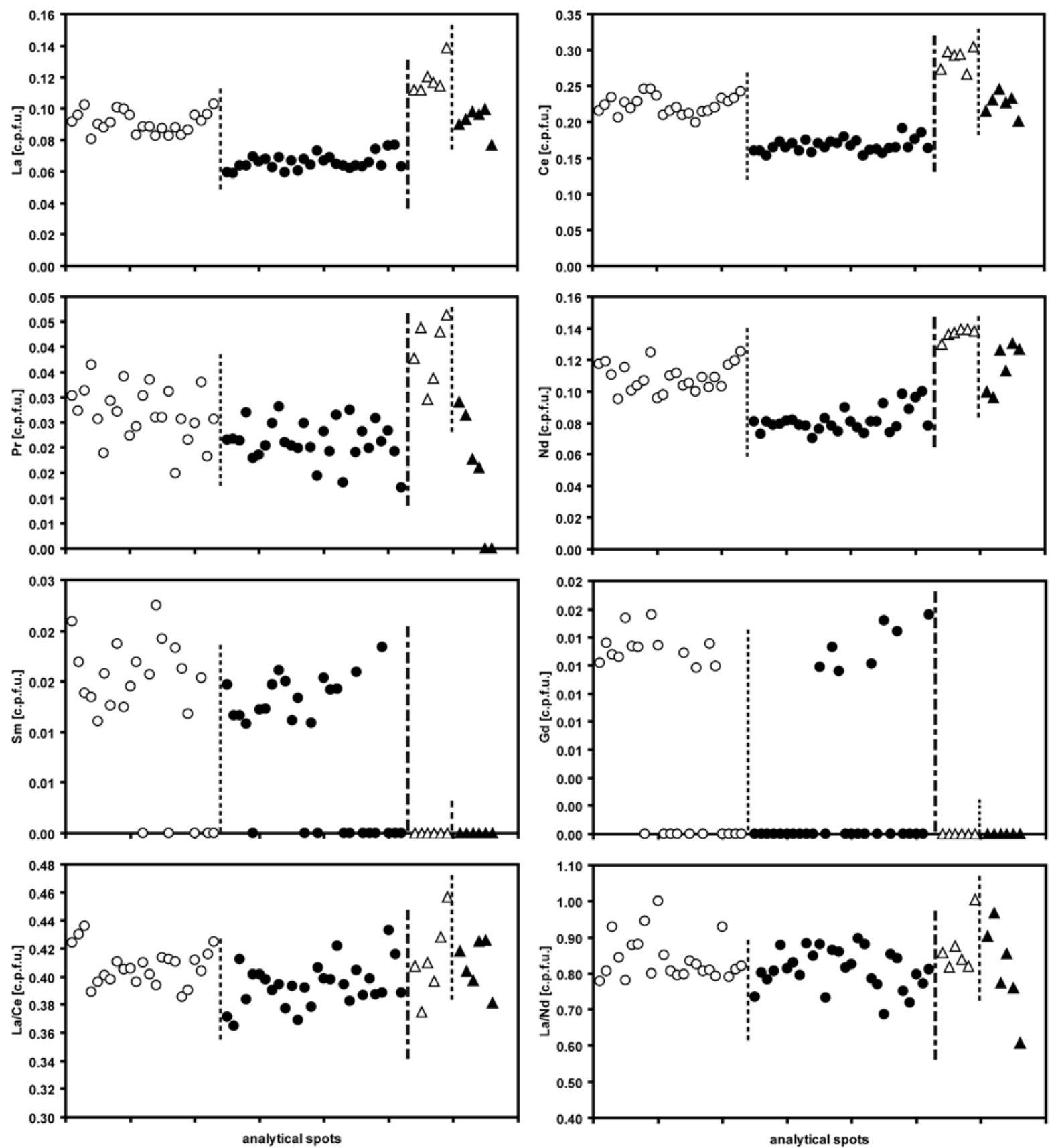

Text-fig. 6 B. Plots showing compositional variations between dark and bright domains in (Ap-1) the fluorapatite present as individual grains; and (Ap-2) the fluorapatite in contact with the fluorbritholite shown in Figure 5. The cations are calculated on the basis of $13 \mathrm{O}$ atoms

Text-fig. 7. Plot of formula proportions $(\mathrm{Y}+\mathrm{REE}+\mathrm{P}) \mathrm{vs}$. $(\mathrm{Th}+\mathrm{Si})$ calculated on the basis of $4 \mathrm{O}$ atoms for the monazite from the mariupolite. Dashed lines represent the huttonitic substitution (Th,U)SiREE ${ }_{-1} \mathrm{P}_{-1}$ and cheralitic substitution $\mathrm{Ca}(\mathrm{Th}, \mathrm{U}) \mathrm{REE}_{-2}$ (Förster 1998; Linthout 2007)

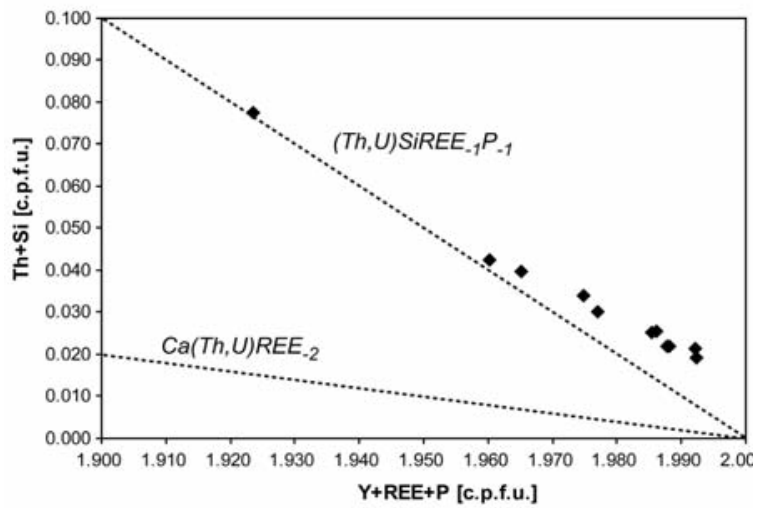




\begin{tabular}{|c|c|c|c|c|c|c|c|c|c|c|}
\hline & 1 & 2 & 3 & 5 & 6 & 7 & 8 & 9 & 10 & 11 \\
\hline $\mathrm{P}_{2} \mathrm{O}_{5}$ & 28.90 & 28.93 & 28.70 & 29.06 & 29.06 & 28.67 & 28.78 & 28.92 & 28.79 & 29.11 \\
\hline $\mathrm{SiO}_{2}$ & 0.43 & 0.58 & 0.49 & 0.49 & 0.37 & 0.38 & 0.58 & 0.67 & 0.65 & 0.41 \\
\hline $\mathrm{ThO}_{2}$ & 0.45 & 0.78 & 0.58 & 0.63 & 0.49 & 0.72 & 1.17 & 1.64 & 1.44 & 0.62 \\
\hline $\mathrm{Y}_{2} \mathrm{O}_{3}$ & 0.11 & 0.08 & 0.13 & 0.11 & & & 0.09 & & & \\
\hline $\mathrm{La}_{2} \mathrm{O}_{3}$ & 14.63 & 15.24 & 14.74 & 14.83 & 16.34 & 16.90 & 16.81 & 21.58 & 21.67 & 16.82 \\
\hline $\mathrm{Ce}_{2} \mathrm{O}_{3}$ & 34.08 & 34.08 & 33.93 & 33.87 & 35.23 & 35.03 & 34.67 & 34.99 & 34.87 & 35.18 \\
\hline $\mathrm{Pr}_{2} \mathrm{O}_{3}$ & 3.96 & 3.97 & 3.92 & 3.98 & 3.79 & 3.76 & 3.63 & 2.95 & 3.15 & 3.60 \\
\hline $\mathrm{Nd}_{2} \mathrm{O}_{3}$ & 14.11 & 13.70 & 13.89 & 13.85 & 12.88 & 12.15 & 12.27 & 8.36 & 8.52 & 12.52 \\
\hline $\mathrm{Sm}_{2} \mathrm{O}_{3}$ & 1.85 & 1.71 & 1.85 & 1.83 & 1.38 & 1.28 & 1.23 & & & 1.21 \\
\hline $\mathrm{Gd}_{2} \mathrm{O}_{3}$ & 0.88 & & 0.73 & 0.98 & & & & & & \\
\hline $\mathrm{CaO}$ & 0.09 & 0.23 & 0.25 & 0.10 & 0.06 & 0.21 & 0.13 & 0.03 & 0.03 & 0.03 \\
\hline total & 99.48 & 99.30 & 99.21 & 99.72 & 99.60 & 99.10 & 99.35 & 99.13 & 99.13 & 99.49 \\
\hline \multicolumn{11}{|c|}{ Cations per formula unit on the basis of 4 oxygens } \\
\hline$P$ & 0.965 & 0.965 & 0.961 & 0.966 & 0.971 & 0.966 & 0.964 & 0.973 & 0.971 & 0.972 \\
\hline $\mathrm{Si}$ & 0.017 & 0.023 & 0.020 & 0.019 & 0.014 & 0.015 & 0.023 & 0.027 & 0.026 & 0.016 \\
\hline Th & 0.004 & 0.007 & 0.006 & 0.006 & 0.005 & 0.007 & 0.011 & 0.016 & 0.014 & 0.006 \\
\hline Y & 0.002 & 0.002 & 0.003 & 0.002 & & & 0.002 & & & \\
\hline $\mathrm{La}$ & 0.213 & 0.221 & 0.215 & 0.215 & 0.238 & 0.248 & 0.245 & 0.316 & 0.318 & 0.245 \\
\hline $\mathrm{Ce}$ & 0.492 & 0.491 & 0.491 & 0.487 & 0.509 & 0.510 & 0.502 & 0.509 & 0.509 & 0.508 \\
\hline $\operatorname{Pr}$ & 0.057 & 0.057 & 0.056 & 0.057 & 0.054 & 0.055 & 0.052 & 0.043 & 0.046 & 0.052 \\
\hline $\mathrm{Nd}$ & 0.199 & 0.193 & 0.196 & 0.194 & 0.181 & 0.173 & 0.173 & 0.119 & 0.121 & 0.176 \\
\hline $\mathrm{Sm}$ & 0.053 & 0.049 & 0.053 & 0.052 & 0.039 & 0.037 & 0.035 & & & 0.035 \\
\hline $\mathrm{Gd}$ & 0.012 & & 0.010 & 0.013 & & & & & & \\
\hline $\mathrm{Ca}$ & 0.004 & 0.010 & 0.011 & 0.004 & 0.003 & 0.009 & 0.005 & 0.001 & 0.001 & 0.001 \\
\hline total & 2.017 & 2.017 & 2.021 & 2.015 & 2.014 & 2.019 & 2.014 & 2.004 & 2.006 & 2.012 \\
\hline REE & 1.027 & 1.013 & 1.024 & 1.020 & 1.022 & 1.022 & 1.010 & 0.987 & 0.994 & 1.016 \\
\hline $\mathrm{Ce} / \mathrm{La}$ & 2.313 & 2.219 & 2.285 & 2.267 & 2.141 & 2.058 & 2.047 & 1.609 & 1.597 & 2.076 \\
\hline $\mathrm{Ce} / \mathrm{Nd}$ & 2.475 & 2.549 & 2.505 & 2.506 & 2.805 & 2.957 & 2.897 & 4.292 & 4.194 & 2.881 \\
\hline $\mathrm{Nd} / \mathrm{La}$ & 0.934 & 0.870 & 0.912 & 0.904 & 0.763 & 0.696 & 0.707 & 0.375 & 0.381 & 0.720 \\
\hline
\end{tabular}

Notes: Blank = below EMP detection limit.

Analyses of Tb, $\mathrm{Dy}, \mathrm{Ho}, \mathrm{Er}, \mathrm{Yb}, \mathrm{U}, \mathrm{Pb}$ and $\mathrm{S}$ are below detection limit and therefore not included.

Table 5. Representative electron microprobe analyses of the secondary monazite

short distance of element transport between the contacting fluorapatite and fluorbritholite-(Ce) in contact has resulted in a partial replacement of the fluorapatite by secondary phosphate REE-host, monazite and also fluorite due to the release of $\mathrm{Ca}$ component from the altered primary phases. Additionally, the secondary parisite formed in the altered domains of the fluorapatite and fluorbritholite(Ce) as a result of this alkali-bearing fluid induced process. The metasomatic alterations proceeded in the presence of the fluid with high $\mathrm{F}, \mathrm{Na}$ and $\mathrm{CO}_{2}$ activity during a late- to post-magmatic low-temperature hydrothermal event.

\section{Acknowledgements}

Leszek Giro and Adam Gaweł are gratefully acknowledged for the assistance with the scanning electron microscope. Piotr Dzierżanowski is thanked for his assistance with the electron microprobe. The authors sincerely thank the reviewers, Ewa Słaby and Ray Macdonald for their helpful comments. The work was financially supported by the AGH - University of Science and Technology (Kraków, Poland), research project no 11.11.140.174.

\section{REFERENCES}

Bea, F. 1996. Residence of REE, Y, Th and U in granites and crustal protoliths; Implications for the chemistry of crustal melts. Journal of Petrology, 37 (3), 521-552.

Berger, A., Gnos, E., Janots, E., Fernandez, A. and Giese, J. 2008. Formation and composition of rhabdophane, bastnäsite and hydrated thorium minerals during alteration: Implications for geochronology and low-temperature processes. Chemical Geology, 254, 238-248.

Bingen, B., Demaiffe, D. and Hertogen, J. 1996. Redistribution of rare earth elements, thorium, and uranium over accessory minerals in the course of amphibolite to granulite facies metamorphism: The role of apatite and monazite in orthogneisses from southwestern Norway. Geochimica et Cosmochimica Acta, 60 (8), 1341-1354

Broska, I. and Siman, P. 1998. The breakdown of monazite in the West-Carpathian Veporic orthogneisses and Tatric granites. Geologica Carpathica, 49, 161-167.

Broska, I., Petrík, I. and Williams, C.T. 2000. Coexisting monazite and allanite in peraluminous granitoids of the Tribec Mountains, Western Carpathians. American Mineralogist, 85, 22-32

Broska, I., Williams, C.T., Janák, M. and Nagy, G. 2005. Alteration and breakdown of xenotime-(Y) and monazite- 
(Ce) in granitic rocks of the Western Carpathians, Slovakia. Lithos, 82, 71-83.

Budzyń, B., Hetherington, C.J., Williams, M.L., Jercinovic, M.J. and Michalik, M. 2010. Fluid-mineral interactions and constraints on monazite alterations during metamorphism. Mineralogical Magazine, 74 (4), 633-655

Budzyń B., Harlov D.E., Williams M.L. and Jercinovic M.J. 2011. Experimental determination of stability relations between monazite, fluorapatite, allanite, and REE-epidote as a function of pressure, temperature, and fluid composition. American Mineralogist, 96, 1547-1567.

Claeson, D.T. 2002. Stability of REE-bearing minerals in a metaluminous leucotonalite from the Eriksberg gabbro, Transscandinavian Igneous Belt, Sweden. Neues Jahrbuch für Mineralogie, Abhandlungen, 177 (3), 277-291.

Donskoy, A.N. 1982. The nepheline complex of alkaline Oktyabr'skii massif, pp. 1-150. The Ukrainian Academy of Science, Kiev. [In Ukrainian]

Dumańska-Słowik, M. Sikorska, M. and Heflik, W. 2011a. Dissolved-recrystallized zircon from mariupolite in the Mariupol Massif, Priazovje (SE Ukraine). Acta Geologica Polonica, 61 (3), 277-288.

Dumańska-Słowik, M., Baranov, P, Heflik, W., NatkaniecNowak, L., Shevchenko, S. and Tsotsko, L.I. 2011 b. Mariupolites of the Oktyabrsky Massif (SE Ukraine) a less known rocks in the gemstone trade. Zeitschrift der Deutschen Gemmologischen Gesellschaft, 60, 37-48.

Finger, F., Broska, I., Roberts, M.P. and Schermaier, A. 1998. Replacement of primary monazite by apatite-allanite-epidote coronas in an amphibolite facies granite gneiss from the eastern Alps. American Mineralogist, 83, 248-258.

Finger, F. and Krenn, E. 2007. Three metamorphic monazite generations in a high-pressure rock from the Bohemian Massif and the potentially important role of apatite in stimulating polyphase monazite growth along a PT loop. Lithos, 95, 103-115.

Fleet, M.E., Liu, X. and Pan, Y. 2000. Rare-earth elements in chlorapatite $\left[\mathrm{Ca}_{10}\left(\mathrm{PO}_{4}\right) 6 \mathrm{Cl}_{2}\right]$ : Uptake, site preference, and degradation of monoclinic structure. American Mineralogist, 85, 1437-1446.

Harlov, D.E., Förster, H.J. and Schmidt, C. 2003. High P-T experimental metasomatism of a fluoroapatite with significant britholite and fluorellesadite components: implications for LREE mobility during granulite-facies metamorphism. Mineralogical Magazine, 67 (1), 61-72.

Harlov, D.E. and Förster, H.J. 2003. Fluid-induced nucleation of (Y+REE)-phosphate minerals within apatite: Nature and experiment. Part II. Fluorapatite. American Mineralogist, 88, 1209-1229.

Harlov, D.E., Wirth R. and Förster, H.J. 2005. An experimental study of dissolution-reprecipitation in fluoroapatite: fluid infiltration and the formation of monazite.
Contributions to Mineralogy and Petrology, 150, 268286.

Harlov, D.E., Marschall, H.R. and Hanel, M. 2007. Fluorapatite-monazite relationships in granulite-facies metapelites, Schwarzwald, southwest Germany. Mineralogical Magazine, 71 (2), 223-234.

Harlov, D.E., Wirth, R. and Hetherington, C.J. 2011. Fluidmediated partial alteration in monazite: the role of coupled dissolution-reprecipitation in element redistribution and mass transfer. Contributions to Mineralogy and Petrology, 162, 329-348.

Harlov, D.E. and Wirth, R. 2012. Experimental incorporation of Th into xenotime at middle to lower crustal $P$ - $T$ utilizing alkali-bearing fluids. American Mineralogist, 97, 641-652.

Hetherington, C.J. and Harlov, D.E. 2008. Metasomatic thorite and uraninite inclusions in xenotime and monazite from granitic pegmatites, Hidra anorthosite massif, southwestern Norway: Mechanics and fluid chemistry. American Mineralogist, 93, 806-820.

Hetherington, C.J., Harlov, D.E. and Budzyń, B. 2010. Experimental metasomatism of monazite and xenotime: mineral stability, REE mobility and fluid composition. Mineralogy and Petrology, 99 (3-4), 165-184

Hughes, J.M. and Rakovan, J. 2002. The Crystal Structure of Apatite, $\mathrm{Ca}_{5}\left(\mathrm{PO}_{4}\right)_{3}(\mathrm{~F}, \mathrm{OH}, \mathrm{Cl})$. In: M.J. Kohn, J. Rakovan and J.M. Hughes (Eds), Phosphates - Geochemical, Geological and Materials Importance. Reviews in Mineralogy and Geochemistry, 48, 1-12.

Janots, E., Negro, F., Brunet, F., Goffé, B., Engi, M. and Bouybaouène, M.L. 2006. Evolution of the REE mineralogy in HP-LT metapelites of the Sebtide complex, Rif, Morocco: Monazite stability and geochronology. Lithos, 87, 214-234.

Janots, E., Engi, M., Berger, A., Allaz, J., Schwarz, J.-O. and Spandler, C. 2008. Prograde metamorphic sequence of REE minerals in pelitic rocks of the Central Alps: implications for allanite-monazite-xenotime phase relations from 250 to $610^{\circ} \mathrm{C}$. Journal of Metamorphic Geo$\log y, 26$ (5), 509-526.

Janots, E., Berger, A. and Engi, M., 2011. Physico-chemical control on the REE minerals in chloritoid-grade metasediments from a single outcrop (Central Alps, Switzerland). Lithos, 121, 1-11.

Kempe, U., Lehmann, B., Wolf, D., Rodionov, N., Bombach, K., Schwengfelder, U. and Dietrich, A. 2008. U-Pb SHRIMP geochronology of Th-poor, hydrothermal monazite: An example from the Llallagua tin-porphyry deposit, Bolivia. Geochimica et Cosmochimica Acta, 72, 4352-4366.

Krenn, E. and Finger, F. 2007. Formation of monazite and rhabdophane at the expense of allanite during Alpine low temperature retrogression of metapelitic basement rocks 
from Crete, Greece: Microprobe data and geochronological implications. Lithos, 95, 130-147

Krivdik, S.G., Nivin, V.A., Kul'chitskaya, A.A., Voznak, D.K., Kalinichenko, A.M., Zagnitko, V.N. and Dubyna, A.V. 2007. Hydrocarbons and other volatile components in alkaline rocks from the Ukrainian Shield and Kola Penisula. Geochemistry International, 45 (3), 270-294.

Lee, D.E. and Dodge, F.C.W. 1964. Accessory minerals in some granitic rocks in California and Nevada as a function of calcium content. American Mineralogist, 49, 1660-1669.

Lee, D.E. and Bastron, H. 1967. Fractionation of rare-earth elements in allanite and monazite as related to geology of the Mt. Wheeler mine area, Nevada. Geochimica et Cosmochimica Acta, 31, 339-356.

Morozewicz, J. 1902. Über Mariupolit, ein extremes Glied der Elaeolithsyenite. Tschermaks Mineralogische und Petrographische Mitteilungen 21, 238-246.

Morozewicz, J. 1929. Mariupolite and its relatives. Prace Polskiego Instytutu Geologicznego 2 (3), p. 130. [In Polish]

Ondrejka, M., Uher, P., Putiš, M., Broska, I., Bačík, P., Konečný, P. and Schmidt, I. 2012. Two-stage breakdown of monazite by post-magmatic and metamorphic fluids: An example from the Veporic orthogneiss, Western Carpathians, Slovakia. Lithos, doi: 10.1016/j.lithos. 2012.03.012

Pan, Y. and Fleet, M.E. 1996. Rare element mobility during prograde granulite facies metamorphism: significance of fluorine. Contributions to Mineralogy and Petrology, 123, 251-262.

Pan, Yu. and Fleet, M. 2002. Compositions of apatite-group minerals: substitution mechanisms and controlling factors. In: M.J. Kohn, J. Rakovan, J.M. Hughes (Eds), Phosphates - Geochemical, Geological and Materials Importance. Reviews in Mineralogy and Geochemistry, 48, 13-49.

Piccoli, P.M. and Candela, P.A. 2002. Apatite in igneous systems. In: M.J. Kohn, J. Rakovan, J.M. Hughes (Eds), Phosphates - Geochemical, Geological and Materials Importance. Reviews in Mineralogy and Geochemistry, 48, 255-292.

Pouchou, I. L. and Pichoir, F. 1985. "PAP” (phi-rho-z) procedure for improved quantitative microanalysis. In: I.T. Armstrong (Ed.), Microbeam Analysis, pp. 104-106. San Francisco Press; San Francisco.

Putnis, A. 2002. Mineral replacement reactions: from macroscopic observations to microscopic mechanisms. Mineralogical Magazine, 66, 689-708.

Putnis, A. 2009. Mineral replacement reactions. In: E.H. Oelkers and J. Schott (Eds), Thermodynamics and Kinetics of Water-Rock Interaction. Reviews in Mineralogy and Geochemistry, 70, 87-124.
Rasmussen, B. and Muhling, J.R. 2009. Reactions destroying detrital monazite in greenschist-facies sandstones from the Witwatersrand basin, South Africa. Chemical Geology, 264, 311-327.

Read, D., Andreoli, M.A.G., Knoper, M., Williams, C.T. and Jarvis, N. 2002. The degradation of monazite: Implications for the mobility of rare-earth and actinide elements during low-temperature alteration. European Journal of Mineralogy, 14, 487-498.

Rønsbo, J.G. 1989. Coupled substitution involving REEs and $\mathrm{Na}$ and $\mathrm{Si}$ in apatites in alkaline rocks from the Llimaussag intrusion, South Greenland, and the petrological implications. American Mineralogist, 74, 896-901.

Rønsbo, J.G. 2008. Apatite in the Llimaussag alkaline complex: Occurrence, zonation and compositional variation. Lithos, 106, 71-82.

Seydoux-Guillaume, A.M., Paquette, J.L., Wiedenbeck, M., Montel, J.M., and Heinrich, W. (2002a) Experimental resetting of the U-Th-Pb systems in monazite. Chemical Geology, 191, 165-181.

Sharygin, V.V., Krivdik, S.G., Pospelova, L.N. and Dubina, A.V. 2009. Zn-kupletskite and hendricksite in the agpaitic phonolites of the Oktyabrskii Massif, Azov Region, Ukraine. Doklady Earth Sciences, 425A (3), 499504.

Solodov, N.A. 1985. The mineralo-genesis of rare metal formations, pp. 1-225. Niedra. [In Ukrainian]

Spear, F.S. 2010. Monazite-allanite phase relations in metapelites. Chemical Geology, 279, 55-62.

Teufel, S. and Heinrich, W. 1997. Partial resetting of the U$\mathrm{Pb}$ isotope system in monazite through hydrothermal experiments: An SEM and U-Pb isotope study. Chemical Geology, 137, 273-281.

Tichonienkova, R.J, Osokin, J.D. and Gonzjejev, A.A. 1967. Rare-metals metasomatites of alkaline massives, pp. 1196. Nauka. [In Ukrainian]

Tropper, P. and Manning, C.E. 2007. The solubility of fluorite in $\mathrm{H}_{2} \mathrm{O}$ and $\mathrm{H}_{2} \mathrm{O}-\mathrm{NaCl}$ at high pressure and temperature. Chemical Geology, 242, 199-306.

Tomkins, H.S. and Pattison, D.R.M. 2007. Accessory phase petrogenesis in relation to major phase assemblages in pelites from the Nelson contact aureole, southern British Columbia. Journal of Metamorphic Geology, 25, 401421.

Upadhyay, D. and Pruseth, K.L. 2012. Fluid-induced dissolution breakdown of monazite from Tso Morari complex, NW Himalayas: evidence for immobility of trace elements. Contributions to Mineralogy and Petrology, doi: 10.1007/s00410-012-0739-3.

Williams, M.L., Jercinovic, M.J., Harlov, D.E., Budzyń, B. and Hetherington, C.J. 2011. Resetting monazite ages during fluid-related alteration. Chemical Geology, 283, 218-225. 
STABILITY RELATIONSHIPS OF REE-BEARING PHOSPHATES IN AN ALKALI-RICH SYSTEM

Wing, B., Ferry, J.M. and Harrison, T.M. 2003. Prograde destruction and formation of monazite and allanite during contact and regional metamorphism of pelites: petrology and geochronology. Contributions to Mineralogy and Petrology, 145, 228-250

Volkova, T.P. 2000. The genesis and ore mineralization of al- kaline rocks from the Oktyabr'skii Massif. Sbornik nauchnykh trudov, 4, 9-10. [In Ukrainian]

Volkova, T.P. 2001. The productivity criterion of REE and ore mineralization within rocks of the Oktyabr'skii Massif Naukovi praci DonDTU., 36, 63-69. [In Ukrainian]

Manuscript submitted: $15^{\text {th }}$ June 2011

Revised version accepted: $15^{\text {th }}$ June 2012 